\title{
Crucial Role of $\mathrm{CB}_{2}$ Cannabinoid Receptor in the Regulation of Central Immune Responses during Neuropathic Pain
}

\author{
Ildiko Racz, ${ }^{1 *}$ Xavier Nadal, ${ }^{3 *}$ Judith Alferink, ${ }^{1,2 *}$ Josep E. Baños, ${ }^{3}$ Jennifer Rehnelt, ${ }^{1}$ Miquel Martín, ${ }^{3}$ Belén Pintado, ${ }^{4}$ \\ Alfonso Gutierrez-Adan, ${ }^{4}$ Elena Sanguino, ${ }^{5}$ Jorge Manzanares, ${ }^{5}$ Andreas Zimmer, ${ }^{1}$ and Rafael Maldonado ${ }^{3}$ \\ ${ }^{1}$ Institute of Molecular Psychiatry and ${ }^{2}$ Department of Psychiatry, University of Bonn, 53105 Bonn, Germany, ${ }^{3}$ Laboratori de Neurofarmacologia, Facultat \\ de Ciències de la Salut i de la Vida, Universitat Pompeu Fabra, Parc de Recerca Biomèdica de Barcelona, 08003 Barcelona, Spain, ${ }^{4}$ Departamento de \\ Reproducción Animal y Conservación de Recursos Zoogenéticos, Instituto Nacional de Investigación y Tecnología Agraria, 28040 Madrid, Spain, and \\ ${ }^{5}$ Instituto de Neurociencias de Alicante, Universidad Miguel Hernández-Consejo Superior de Investigaciones Científicas, 03550 Alicante, Spain
}

Neuropathic pain is a clinical manifestation of nerve injury difficult to treat even with potent analgesic compounds. Here, we used different lines of genetically modified mice to clarify the role played by $\mathrm{CB}_{2}$ cannabinoid receptors in the regulation of the central immune responses leading to the development of neuropathic pain. $\mathrm{CB}_{2}$ knock-out mice and wild-type littermates were exposed to sciatic nerve injury, and both genotypes developed a similar hyperalgesia and allodynia in the ipsilateral paw. Most strikingly, knock-outs also developed a contralateral mirror image pain, associated with an enhanced microglial and astrocytic expression in the contralateral spinal horn. In agreement, hyperalgesia, allodynia, and microglial and astrocytic activation induced by sciatic nerve injury were attenuated in transgenic mice overexpressing $\mathrm{CB}_{2}$ receptors. These results demonstrate the crucial role of $\mathrm{CB}_{2}$ cannabinoid receptor in modulating glial activation in response to nerve injury. The enhanced manifestations of neuropathic pain were replicated in irradiated wild-type mice reconstituted with bone marrow cells from $\mathrm{CB}_{2}$ knock-outs, thus demonstrating the implication of the $\mathrm{CB}_{2}$ receptor expressed in hematopoietic cells in the development of neuropathic pain at the spinal cord.

Key words: $\mathrm{CB}_{2}$ cannabinoid receptor; microglia; astrocytes; neuropathic pain; bone marrow chimera; neuroinflammation

\section{Introduction}

The interest in the medical use of cannabinoid ligands has greatly increased in the last few years. Two cannabinoid receptors, $\mathrm{CB}_{1}$ and $\mathrm{CB}_{2}$ (Matsuda et al., 1990; Munro et al., 1993), have been extensively studied to clarify their involvement in several pathophysiological situations in which cannabinoid ligands could be potential therapeutic agents, including pain management. Indeed, cannabis derivatives have been used for centuries as analgesic compounds, and cannabinoid agonists have been reported to be effective on several animal models of acute and chronic pain (Pertwee, 2001). However, the psychoactive effects of these agonists could represent a serious limitation for their clinical use. $\mathrm{CB}_{1}$ receptors, mainly located in the CNS (Tsou et al., 1998),

\footnotetext{
Received July 18, 2008; revised Sept. 19, 2008; accepted Sept. 26, 2008.

This work was supported by grants from the National Institute on Drug Abuse (1R01-DA016768-0111) (R.M., A.Z.), European Commission [Framework VI, GENADDICT 0J 2004/C164, 005166 (R.M., A.Z.); PHECOM, LSHM-CT2007-037669 (R.M.)], Ministerio de Educación y Ciencia (BFU2004-00920/BFl; SAF2007-64062) (R.M.), Generalitat de Catalunya (R.M.), Deutsche Forschungsgemeinschaft (SFB645; FOR926) (A.Z.), and Bundesministerium für Bildung und Forschung (NGFN2) (A.Z.). We thank Dr. Patricia Murtra for her contribution in the histological experiments, Dr. Bernardo Castellano for helping in the microglia protocols, Drs. Patricia Robledo and Miguel Angel Serra for critical comments on this manuscript, and Edda Erxlebe, Julia Essig, Astrid Markert, Daniela Mauer, Dr. David Otte, Karola Poppensieker, Friederike Stammer, and Öznur Yilmaz for expert help.

*I.R., X.N., and J.A. contributed equally to this work.

Correspondence should be addressed to either of the following: Andreas Zimmer, Institute of Molecular Psychiatry, University of Bonn, Sigmund-Freud-Strasse 25, 53105 Bonn, Germany, E-mail: a.zimmer@uni-bonn.de; or Rafael Maldonado, Laboratori de Neurofarmacologia, Facultat de Ciéncies de la Saluti de la Vida, Universitat Pompeu Fabra, C/Dr Aiguader 80, 08003 Barcelona, Spain, E-mail: rafael.maldonado@upf.edu.

D0I:10.1523/JNEUROSCI.3400-08.2008

Copyright $\odot 2008$ Society for Neuroscience $\quad$ 0270-6474/08/2812125-11\$15.00/0
}

seem to be selectively involved in cannabinoid psychoactive effects (Ledent et al., 1999; Zimmer et al., 1999). Interestingly, the activation of $\mathrm{CB}_{1}$ receptors expressed in peripheral nociceptors but not in the CNS attenuates neuropathic pain in rodents (Agarwal et al., 2007). The identification of $\mathrm{CB}_{2}$ receptors in glial cells (Zhang et al., 2003; Beltramo et al., 2006) has opened new therapeutic approaches for these ligands. $\mathrm{CB}_{2}$ receptors have been also proposed to be present in neurons (Van Sickle et al., 2005), although this issue is still controversial. $\mathrm{CB}_{2}$ receptor activation induces analgesic effects in several animal models (Beltramo et al., 2006; Ibrahim et al., 2006; Bingham et al., 2007; Giblin et al., 2007), and selective $\mathrm{CB}_{2}$ agonists could be potentially used as analgesic drugs, thus circumventing psychoactive side effects of $\mathrm{CB}_{1}$ agonists (Whiteside et al., 2007).

In the spinal cord, $\mathrm{CB}_{2}$ receptor expression was induced during neuropathic pain produced by peripheral nerve injury in parallel with the simultaneous expression of activated microglia (Zhang et al., 2003). Microglia seem to be involved in the development of neuropathic pain through the release of several cytokines, which are known to produce neuron sensitization in the spinal cord (DeLeo and Yezierski, 2001; Clark et al., 2007). Interestingly, $\mathrm{CB}_{2}$ receptor stimulation has been reported to attenuate microglial activation (Ehrhart et al., 2005; Romero-Sandoval and Eisenach, 2007) and $\mathrm{CB}_{2}$ agonists induce analgesic effects in neuropathic pain models (Ibrahim et al., 2003). Although these studies suggest a potential role for $\mathrm{CB}_{2}$ receptors in the modulation of neuropathic pain, the mechanism underlying these analgesic ef- 
fects and the exact involvement of $\mathrm{CB}_{2}$ receptors in the development of neuropathic pain has not been clarified yet. We have therefore now used genetically modified mice lacking $\left(\mathrm{CB}_{2}{ }^{-1-}\right)$ (Buckley et al., 2000; Ofek et al., 2006) or overexpressing $\mathrm{CB}_{2}$ cannabinoid receptors to evaluate the participation of these receptors in the behavioral and histological consequences of the development of neuropathic pain after partial sciatic nerve injury. Additional experiments using irradiated wild-type (WT) $\left(\mathrm{CB}_{2}{ }^{++}\right)$mice receiving bone marrow transplantation from $\mathrm{CB}_{2}{ }^{-1-}$ have been performed to identify the biological mechanisms involved in the regulation of neuropathic pain responses by $\mathrm{CB}_{2}$ receptors.

\section{Materials and Methods}

Animal experimental conditions. Animals were housed in groups of three to five and had ad libitum access to water and food. The housing conditions were maintained at $21 \pm 1{ }^{\circ} \mathrm{C}$ and $55 \pm 10 \%$ relative humidity in a controlled light/dark cycle (light on between 8:00 A.M. and 8:00 P.M.). All experimental procedures and animal husbandry were conducted according to standard ethical guidelines (European Community Guidelines on the Care and Use of Laboratory Animals 86/609/EEC) and approved by the local ethical committee (Comite Etico Experimental Animal-Instituto Municipal de Asistencia Sanitaria/Universitat Pompeu Fabra, Bezirksregierung Köln). All experiments were performed under blind conditions.

$\mathrm{CB}_{2}$ knock-out mice. Male and female $\mathrm{CB}_{2}$ knock-outs $\left(\mathrm{CB}_{2}{ }^{-1-}\right)$ mice and wild-type littermates $\left(\mathrm{CB}_{2}{ }^{+/+}\right)$on a $\mathrm{C} 57 \mathrm{BL} / 6 \mathrm{~J}$ congenic background (Buckley et al., 2000), 3 months of age and weighing 23-29 $\mathrm{g}$ at the beginning of the experiments, were used.

Plasmid constructs and generation of transgenic mice overexpressing $\mathrm{CB}_{2}$. The open reading (ORF) of the murine $\mathrm{CB}_{2}$ receptor was isolated by $\mathrm{PCR}$ amplification from mice brain mRNA, using primers which created a XhoI restriction enzyme site adjacent to the translation start and stop sites. The expression vector MoPrP.Xho (Watkins et al., 2003) was used for the production of transgenic mice. This vector contains the murine PrP promoter, exon 1, intron 1, exon 2, and 3 ' untranslated sequences. The $\mathrm{CB}_{2}$ receptor ORF was cloned in exon 2 of MoPrP.Xho construct (Watkins et al., 2003). The PrP- $\mathrm{CB}_{2}$ transgene was excised from the plasmid vector with restriction endonuclease NotI leading to DNA fragments of $12 \mathrm{~kb}$. Transgenic founders were crossed with outbred CD-1 mice for seven generations. The presence of the transgene was determined by PCR using specific primers again exon 2 of PrP (5' -CCAGCCTCCACCACCATGTGGC) and $\mathrm{CB}_{2}$ receptor (5'-AGCCACCGTTGGAGCCGTTG).

Analysis of $\mathrm{CB}_{2}$ mRNA expression by real-time PCR. Mice were killed by cervical dislocation. Brains, and cervical and thoracic sections of the spinal cord were removed rapidly, fresh-frozen, and stored immediately at $-80^{\circ} \mathrm{C}$ until use. Brain sections were cut at $500 \mu \mathrm{m}$ at different levels containing the regions of interest: thalamus and periaqueductal gray (PAG). These sections were obtained according to Paxinos and Franklin (2001), mounted onto slides, and stored at $-80^{\circ} \mathrm{C}$ until use. Sections were dissected following the method described by Palkovits (1983). Total RNA was extracted from brain punches and spinal cord sections using Ultraspec RNA (Biotecx). After DNase digestion, the reverse transcription was performed following the manufacturer's instructions of Epicenter Technologies Corporation. Quantitative PCR was performed in three replicates using a Rotorgene 3000 Real Time Cycler (Corbett Research) and SYBR Green (Invitrogen) as a double-stranded DNA-specific fluorescent dye (Gutiérrez-Adán et al., 2004). Primers for transgenic quantification were the same as described above. Primers for the quantification of the expression of endogenous $\mathrm{CB}_{2}$ were $5^{\prime}$-TCTGGAAAGCCCACCGGCATGTAG and 5'-CAAGGCACAGCATGGAACAGAAGG. The comparative CT method was used for quantification of expression levels (Gutiérrez-Adán et al., 2004). A GADPH cDNA was used as normalization control to ensure constant GADPH levels in all samples regardless of experimental conditions. One-way repeated-measures ANOVA (followed by multiple pairwise comparisons using Student-
Newman-Keuls method) were used for the analysis of differences in mRNA expression assayed by quantitative reverse transcription-PCR.

Generation of bone marrow chimeric mice. Bone marrow (BM) cells were harvested by flushing tibias and femurs from 6- to 8-week-old $\mathrm{CB}_{2}{ }^{+/+}$or $\mathrm{CB}_{2}{ }^{-1-}$ male donor mice with PBS. Single-cell suspensions were prepared by filtering $\mathrm{BM}$ cells through a $100 \mu \mathrm{m}$ cell strainer. CD45.1 congenic male recipient mice were given lethal total body irradiation $(900 \mathrm{rad})$, and $24 \mathrm{~h}$ later were intravenously reconstituted with $5 \times 10^{6}$ BM cells. The animals received intraperitoneally $150 \mathrm{mg} / \mathrm{kg}$ amoxicillin and $15 \mathrm{mg} / \mathrm{kg}$ clavulanic in a volume of $0.1 \mathrm{ml} / 10 \mathrm{~g}$ for $10 \mathrm{~d}$ starting on the day of transfer. After 8 weeks of engraftment, the efficiency of the reconstitution was assessed by flow cytometric analysis of peripheral blood lymphocytes (PBLs). All mice were bled from the tail vein and PBLs were analyzed by flow cytometry (FACS Canto Flow Cytometer; BD Biosciences; FlowJo analysis software; Tree Star) with monoclonal antibodies against CD45.1 and CD45.2 (BD Biosciences) to determine the degree of chimerism. Only BM-chimeric mice that showed $>93 \%$ reconstitution efficiency with donor cells were chosen for the experiments. $\mathrm{CB}_{2}{ }^{+/+}$mice reconstituted with $\mathrm{CB}_{2}{ }^{+/+} \mathrm{BM}$ are referred to as chimera-WT, and $\mathrm{CB}_{2}{ }^{+/+}$animals reconstituted with $\mathrm{CB}_{2}{ }^{-1-} \mathrm{BM}$ are referred to as chimera- $\mathrm{CB}_{2}$.

Preparation of microglia. Brains and spinal cords were removed from perfused mice, and single-cell suspensions were generated and filtered through a $100 \mu \mathrm{m}$ cell strainer. Percoll gradients of 30/37/70\% were performed for fractionation of cells at $1000 \times g$ for $30 \mathrm{~min}$, and brain mononuclear cells were collected from the interface. Flow cytometry was performed as described for PBL analysis of animals.

Behavioral experiments. Hyperalgesia to noxious thermal stimulus (plantar test) and allodynia to cold (cold-plate test) and mechanical stimuli (von Frey stimulation model) were used as outcome measures of neuropathic pain. In the plantar test, the mean paw withdrawal latencies for the ipsilateral and contralateral hindpaws were determined from the average of three separate trials, taken at 5 min intervals to prevent thermal sensitization and behavioral disturbances using a commercially available apparatus (Ugo Basile Biological Research Apparatus) (Hargreaves et al., 1988). The von Frey filament stimulation experiments were conducted with calibrated nylon filaments (North Coast Medical) (see Figs. 1,4) or with a Dynamic Aesthesiometer (Ugo Basile Biological Research Apparatus) (see Fig. 6). The threshold of response was calculated by using the up-down Excel program generously provided by the Basbaum Laboratory. Clear paw withdrawal, shaking, or licking was considered to be a nociceptive-like response (Chaplan et al., 1994). In the cold-plate test (Columbus Instruments), the number of elevations of each hindpaw was recorded in the mice exposed to the cold plate $(5 \pm$ $0.5^{\circ} \mathrm{C}$ ) during $5 \mathrm{~min}$.

In a first experimental sequence, $\mathrm{CB}_{2}{ }^{-1-}$ (16 males plus 16 females) and $\mathrm{CB}_{2}{ }^{+/+}$(16 males plus 15 females) were used. In the second study, transgenic mice overexpressing $\mathrm{CB}_{2}$ receptors ( 12 males plus 12 females) and $\mathrm{CB}_{2}{ }^{+/+}$(12 males plus 12 females) were used. Finally, $\mathrm{CB}_{2}{ }^{-1-}(10$ males), $\mathrm{CB}_{2}{ }^{-1-}$ (10 males), chimera- $\mathrm{CB}_{2}$ (12 males), and chimera-WT (10 males) mice were evaluated. Mice were first habituated for $1 \mathrm{~h}$ to each different experimental test once daily during $4 \mathrm{~d}$. After the habituation period, baseline responses were established during 2 consecutive days for each paradigm in the following sequence: von Frey model, plantar test (30 min later), and cold-plate test (15 min later). All the behavioral tests were performed in the same group of animals. One day after baseline measurements, sciatic nerve injury was induced. A partial ligation of the sciatic nerve at midthigh level just proximal to the trifurcation was performed with one thigh ligature using a 9-0 silk thread to induce neuropathic pain, as described previously (Malmberg and Basbaum, 1998). $\mathrm{CB}_{2}{ }^{-1-}$ and $\mathrm{CB}_{2}{ }^{++}$mice were tested in each paradigm on days $3,6,8$, 10 , and 15 after the surgical procedure using the same sequence as for baseline responses. Data were compared each experimental day by using a two-way ANOVA (surgery and genotype as between-group factors) followed by corresponding one-way ANOVA when appropriate.

Immunohistochemistry. At the end of the behavioral experiment, three to five mice per group were deeply anesthetized with ketamine/xylazine $(50 / 10 \mathrm{mg} / \mathrm{kg})$ and then intracardially perfused with heparinized phosphate buffer (PB), followed by $4 \%$ paraformaldehyde. The lumbar region 
of the spinal cord was removed, postfixed in $4 \%$ paraformaldehyde for $2 \mathrm{~h}$, and cryopreserved in $15 \%$ sucrose solution at $4^{\circ} \mathrm{C}$. The section from L2 to L6-S1 of the spinal cord was selected and then embedded in OCT, sliced in $25 \mu \mathrm{m}$ sections on a cryostat, and mounted six sections per mice and two mice per slide in Star frost-coated slides.

The slides were incubated in polyclonal ibal antibody (1:200; Wako Chemicals) for microglia staining or polyclonal GFAP antibody (1:1000; Dako) for astrocyte staining at $4^{\circ} \mathrm{C}$ overnight. The immunohistochemical assays were followed by incubation in the CY3 anti-rabbit secondary antibody (1:500; Jackson Immunoresearch) for ibal or GFAP for $1 \mathrm{~h}$ at room temperature. After washing three times with $0.1 \mathrm{M} \mathrm{PB}$, the slides were mounted with Mowiol.

For the low-magnification images, the stained sections of the lumbar dorsal horn were viewed at $10 \times$ objective and recorded with a Leica DMR microscope equipped with digital camera Leica DFC 300 FX.

Confocal images were obtained using a Leica SP2 confocal microscope, adapted to an inverted Leica DM IRBE microscope. Tissue sections of the lumbar dorsal horn were examined with a $40 \times, 1.25$ numerical aperture oil-immersion Leica Plan Apochromatic objective. CY3 was excited with the $543 \mathrm{~nm}$ line of a green neon laser, and immunofluorescence images of three stained sections were taken for each animal. From each section, images were always recorded of the ipsilateral and contralateral dorsal horns. Nine to fifteen images were analyzed for each experimental group with ImageJ software measuring the percentage of stained occupied area. Data were compared by using one-way ANOVA and least significant difference post hoc analysis.

$\mathrm{CB}_{2}$ staining. The spinal cords were removed and frozen on dry ice without previous perfusion. They were sectioned in a cryostat at $20 \mu \mathrm{m}$ thickness and mounted on glass slides. The tissues were fixed for $30 \mathrm{~min}$ in $4 \%$ formaldehyde dissolved in $0.1 \mathrm{M}$ PBS, $\mathrm{pH}$ 7.3. Next, the slides were incubated for $15 \mathrm{~min}$ in $0.3 \% \mathrm{H}_{2} \mathrm{O}_{2}$, for $60 \mathrm{~min}$ in $0.5 \%$ Triton $\mathrm{X}-100$ and for $2 \mathrm{~h}$ in $3 \% \mathrm{BSA}$. The slides were washed in PBS at least two times for 5 min between each incubation phase. The sections were labeled at $4^{\circ} \mathrm{C}$ for $20 \mathrm{~h}$ using a rabbit polyclonal $\mathrm{CB}_{2}$ primary antibody (1:1000; $\mathrm{Abcam}$ ), for microglia staining with ibal polyclonal primary antibody (1:200; Wako Chemicals), for astrocyte staining with polyclonal GFAP primary antibody (1:1000; Dako), and for neuron staining with fluoresceinconjugated Neu-N (1:500; Millipore Bioscience Research Reagents) primary antibody. The double staining for $\mathrm{CB}_{2}$ receptors and for microglia or for astrocytes using secondary antibody from the same host was performed using the method of Tóth and Mezey (2007). Briefly, after labeling the $\mathrm{CB}_{2}$ receptors, the process was followed by using a Tyramide Signal Amplification System (TSA Plus Fluorescence System; PerkinElmer Life and Analytical Sciences). The slides were incubated for $30 \mathrm{~min}$ in streptavidin-HRP (1:200) dissolved in TNB buffer $(0.1 \mathrm{M}$ Tris, $\mathrm{pH} 7.5,0.15 \mathrm{M} \mathrm{NaCl}, 0.5 \%$ blocking reagent). The sections were washed three times for $5 \mathrm{~min}$ and incubated in fluorophore tyramide (1:100 in amplification reagent) for 6-9 $\mathrm{min}$. The slides were washed in PBS (three times for $5 \mathrm{~min}$ ), and fixed again for $15 \mathrm{~min}$ in $4 \%$ paraformaldehyde. After washing in PBS (three times for $10 \mathrm{~min}$ ), the assay was followed by cooking the slides in the microwave in $10 \mathrm{~mm}$ citrate buffer, $\mathrm{pH} 6$, for 5 $\mathrm{min}$; after cooling (60-90 $\mathrm{min}$ ), they were washed again. Next, the slides were incubated in $0.5 \%$ Triton X-100 and in PBS containing $1 \%$ bovine serum albumin and $10 \%$ goat serum for $60 \mathrm{~min}$. The sections were labeled at $4^{\circ} \mathrm{C}$ for $20 \mathrm{~h}$ using rabbit polyclonal anti-GFAP primary antibody (1:1000; Dako) or rabbit polyclonal ibal primary antibody (1:200; Wako Chemicals). The assay was followed by incubation in Cy3-conjugated donkey anti-rabbit IgG (1:250; Jackson Immunoresearch) secondary antibody. The assays were followed by incubation with FITC-conjugated donkey anti-rabbit (1:250; Jackson Immunoresearch) secondary antibody for microglia or for astrocytes at room temperature for $2 \mathrm{~h}$. The sections were washed in water and mounted in Vectashield Mounting Medium (Vector Laboratories; H-1200). The sections were viewed under fluorescence illumination (Zeiss Axioplan microscope). The images were investigated using JVC (3-CCO) digital camera connected to the microscope with the help of NIS-Elements software (Nikon).

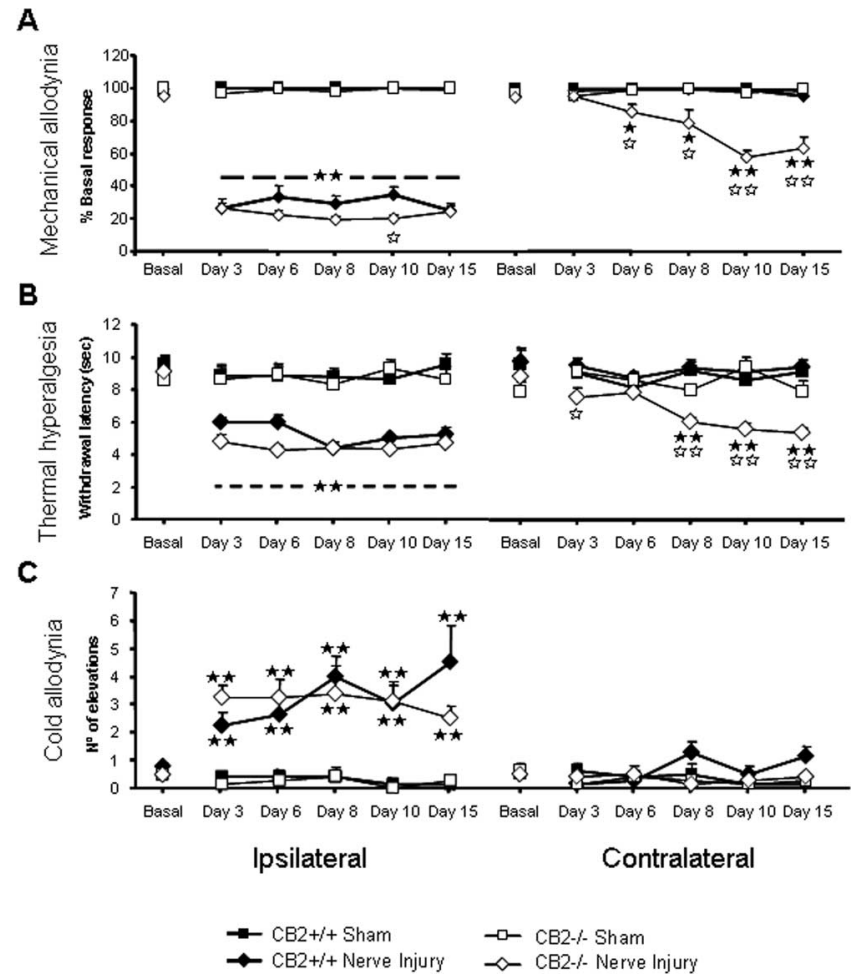

Figure 1. Development of neuropathic pain is enhanced in male $\mathrm{CB}_{2}{ }^{-1-}$ after sciatic nerve injury when compared with $\mathrm{CB}_{2}{ }^{+/+}$. A single tight ligature around one-third or one-half of sciatic nerve was made to induce the neuropathic pain in $\mathrm{CB}_{2}{ }^{-1-}(n=16)$ and $\mathrm{CB}_{2}{ }^{+/+}$mice $(n=16)$. Mice were tested in the ipsilateral and contralateral paw for evaluating mechanical allodynia (von Frey model; percentage of the basal $\mathrm{CB}_{2}{ }^{+/+}$sham-operated values) $(\boldsymbol{A})$, thermal hyperalgesia (plantar test; withdrawal latency in seconds) $(\boldsymbol{B})$, and cold allodynia (coldplate test; number of paw elevations) $(\boldsymbol{C}$ ) on days 3,6,8, 10, and 15 after surgery. The black stars represent comparison between sciatic nerve injury and sham-operated animals. The white stars represent comparison between genotypes. One star, $p<0.05$; two stars, $p<0.01$. Error bars indicate SEM.

\section{Results}

The manifestations of neuropathic pain are enhanced in $\mathrm{CB}_{2}{ }^{-1-}$ mice

Hyperalgesia to a noxious thermal stimulus (plantar test), and allodynia to cold (cold-plate test) and mechanical stimuli (von Frey stimulation model) were first used as outcome behavioral measures of neuropathic pain. Baseline responses of $\mathrm{CB}_{2}{ }^{-1-}$ mice and $\mathrm{CB}_{2}{ }^{+/+}$littermates were similar in the three nociceptive models, and sham operation did not produce any modification of these nociceptive thresholds in both genotypes. Sciatic nerve injury similarly enhanced thermal hyperalgesia and induced mechanical and thermal allodynia in the ipsilateral paw in both $\mathrm{CB}_{2}{ }^{-1-}$ and $\mathrm{CB}_{2}{ }^{+/+}$mice (Fig. 1). Most strikingly, however, the same degree of thermal hyperalgesia and mechanical allodynia also developed in the contralateral paw of $\mathrm{CB}_{2}{ }^{-1-}$ mice, revealing a mirror image of pain. This mirror image was not observed in $\mathrm{CB}_{2}{ }^{+/+}$mice (Fig. 1). A similar result was obtained in both sexes of $\mathrm{CB}_{2}{ }^{-1-}$ and $\mathrm{CB}_{2}{ }^{+1+}$ mice on the three nociceptive behavioral measures (supplemental Fig. 1, available at www.jneurosci.org as supplemental material). In agreement with previous reports (Ibrahim et al., 2006), a trend to enhance basal nociceptive response was observed in the plantar test in $\mathrm{CB}_{2}{ }^{-1-}$ mice, although a significant effect $(p<0.05)$ was only revealed when analyzing data from both genders together. 
Microglial cells are involved in the enhanced manifestations of neuropathic pain in $\mathrm{CB}_{2}{ }^{-/-}$mice

Glial cells are involved in neuropathic pain and express $\mathrm{CB}_{2}$ receptors after nerve injury (Ehrhart et al., 2005). Therefore, we have evaluated glial response in the dorsal horn of the lumbar spinal cord after sciatic nerve injury or sham operation in $\mathrm{CB}_{2}{ }^{-/-}$ and $\mathrm{CB}_{2}{ }^{+/+}$mice to determine its possible involvement in the increased neuropathic pain sensitivity of $\mathrm{CB}_{2}{ }^{-1-}$ animals. Sciatic nerve injury induced a similar enhancement of total microglial cell staining in the dorsal and ventral ipsilateral horn of the spinal cord in $\mathrm{CB}_{2}{ }^{-1-}$ and $\mathrm{CB}_{2}{ }^{+/+}$mice. Interestingly, a similar microglial reaction was observed in the contralateral and ipsilateral horns in $\mathrm{CB}_{2}^{-1-}$, but not in $\mathrm{CB}_{2}{ }^{+/+}$mice (Fig. 2). Similarly, an activation of microglia in the ipsilateral horns in $\mathrm{CB}_{2}{ }^{-/-}$and $\mathrm{CB}_{2}{ }^{+/+}$mice, and a stimulation in the contralateral horns only in $\mathrm{CB}_{2}{ }^{-1-}$ mice were observed. In agreement with these findings, a significant increase of the staining for ibal, a specific marker for microglial cells, was observed in the ipsilateral side after nerve injury in $\mathrm{CB}_{2}{ }^{+/+}$ mice and in the ipsilateral and contralateral side in $\mathrm{CB}_{2}{ }^{-1-}$ mice. This increase was attributable to an enhancement in the number of microglial cells, which show specific morphological changes (Fig. $2 B$ ). Thus, typical resting microglia with a small cell body and thin and large ramifications were observed in sham-operated mice (Fig. $2 \mathrm{~B}$ ). After nerve injury, these resting microglia were present only in the contralateral side of $\mathrm{CB}_{2}^{+/+}$mice. In contrast, the ipsilateral side of $\mathrm{CB}_{2}{ }^{+/+}$mice and both the ipsilateral and contralateral side of $\mathrm{CB}_{2}{ }^{-1-}$ mice contained microglia with an activated phenotype. These cells have bigger cell bodies, as well as thicker and shorter ramifications (Fig. $2 B$ ). The same result was also found in astrocytic responses, with a similar activation in the ipsilateral horns in $\mathrm{CB}_{2}^{-/-}$and $\mathrm{CB}_{2}{ }^{+/+}$ mice, and a selective reaction in the contralateral horns only in $\mathrm{CB}_{2}{ }^{-1-}$ mice (Fig. $2 B$ ). Thus, remarkably, the glial cell activation profile matched exactly the pattern of nociceptive hypersensitivity. Because glial activation and functional responses are inhibited by $\mathrm{CB}_{2}$ receptor stimulation (Ehrhart et al., 2005; Romero-Sandoval and Eisenach, 2007), these results suggest that the suppression of $\mathrm{CB}_{2}$ receptors had a disinhibitory effect on the glial response after sciatic nerve injury, thus leading to exacerbated pain response in these animals, which was mainly revealed in the contralateral side.
A

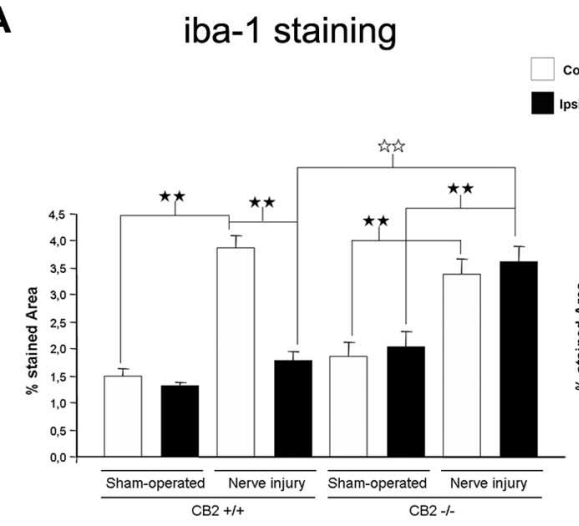

B

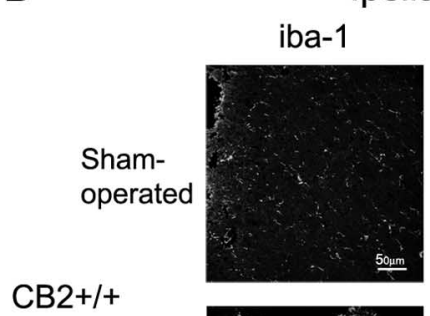

Nerve injury
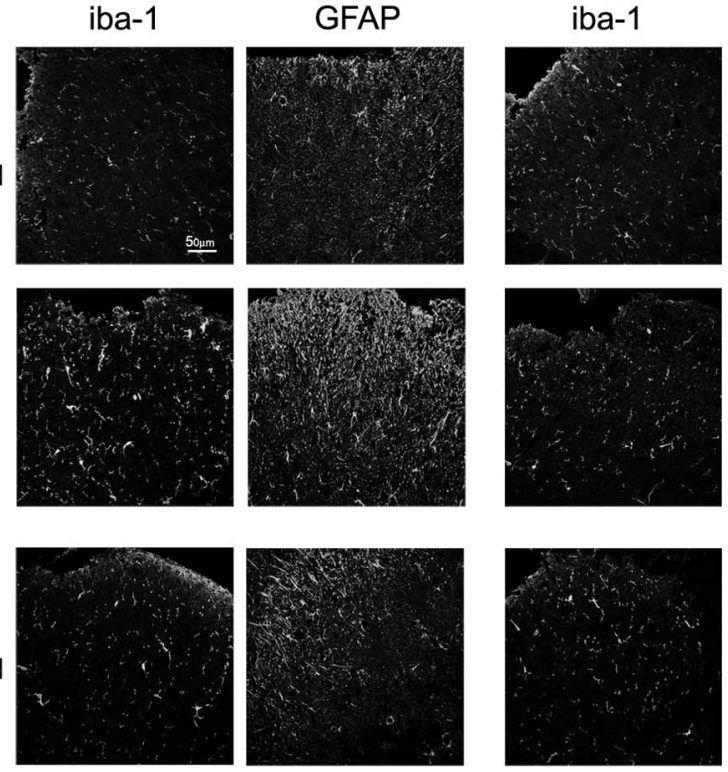

CB2-/-
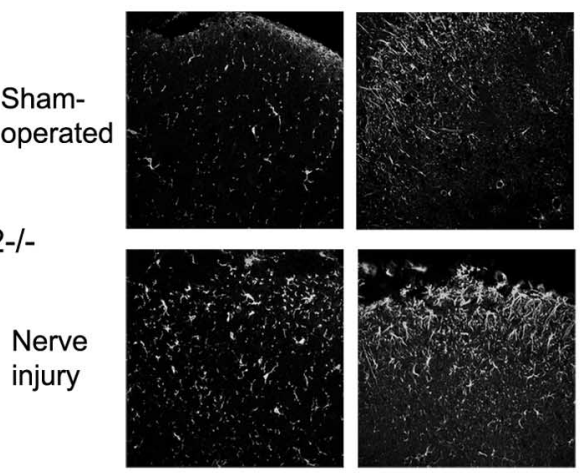

CB2 +/+ (nerve injury)

C
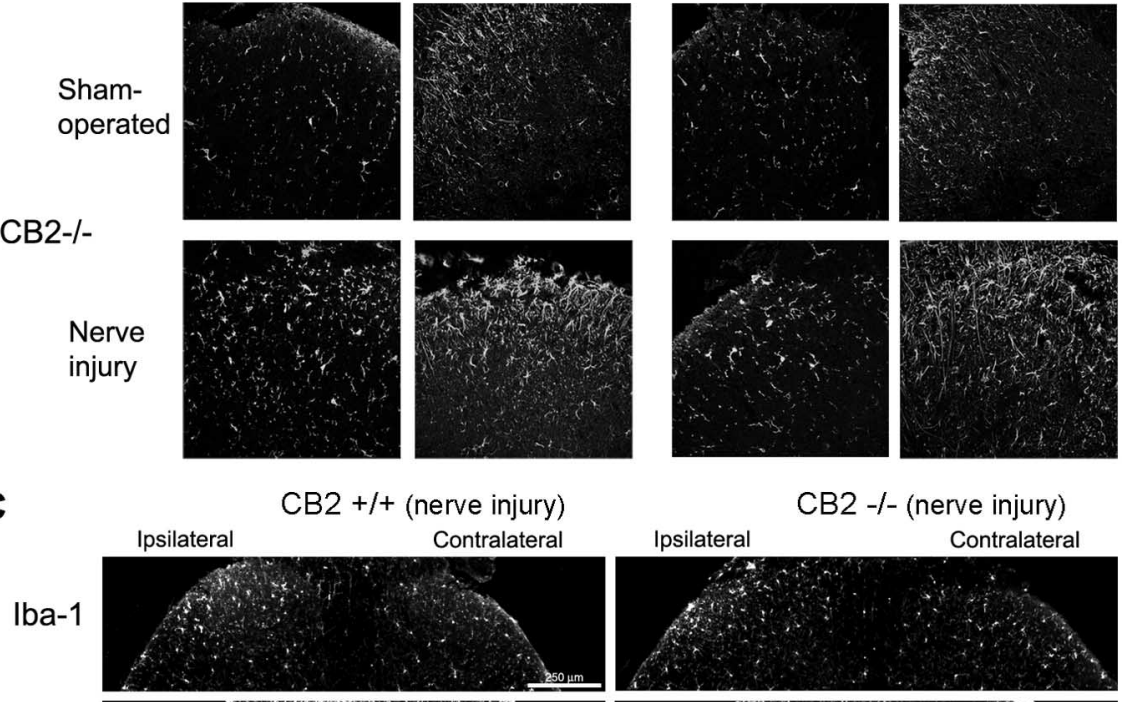

Nerve

injury
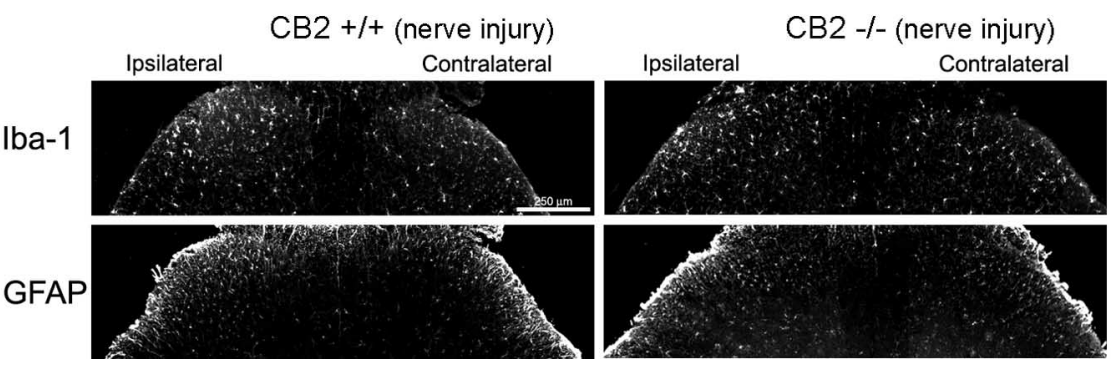

Figure 2. Enhanced glial activation in spinal cord of $\mathrm{CB}_{2}{ }^{-/-}$after sciatic nerve injury when compared with $\mathrm{CB}_{2}{ }^{+/+}$mice. $A$, Increase in iba-1 (microglia) $(n=5)$ and GFAP (astrocyte) $(n=5)$ staining in dorsal horn of lumbar spinal cord after sciatic nerve injury in $\mathrm{CB}_{2}{ }^{-/-}$and in $\mathrm{CB}_{2}{ }^{+/+}$mice. White bars, I psilateral paw; black bars, contralateral paw. Iba-1 and GFAP visualized with $\mathrm{CY} 3$ anti-rabbit (red). Data are expressed as percentage of stained area. The black stars represent comparisons between shamoperated and nerve injury between ipsilateral and contralateral paw. The white stars represent comparisons between genotypes. One star, $p<0.05$; two stars, $p<0.01$. Error bars indicate SEM. $\boldsymbol{B}$, Representative confocal images of the immunostaining of iba- 1 and GFAP recorded with $40 \times$ objective in lumbar dorsal horn of $\mathrm{CB}_{2}{ }^{+/+}$and $\mathrm{CB}_{2}{ }^{-/-}$. C, Representative lowmagnification images of iba-1 and GFAP immunostaining recorded with $10 \times$ objective in the lumbar dorsal horn of sciatic nerve injury $\mathrm{CB}_{2}{ }^{+/+}$and $\mathrm{CB}_{2}{ }^{-/-}$mice. 
A

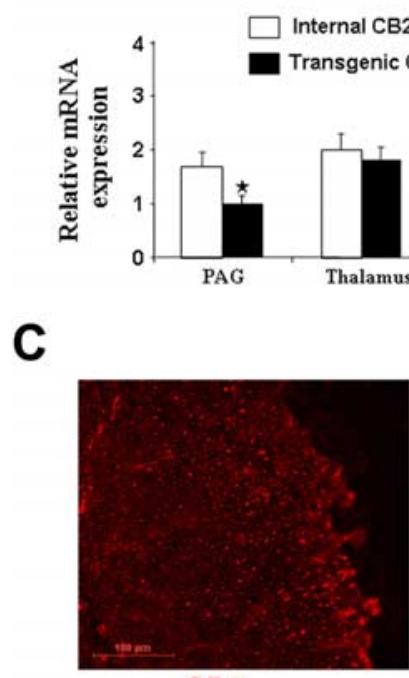

CB2

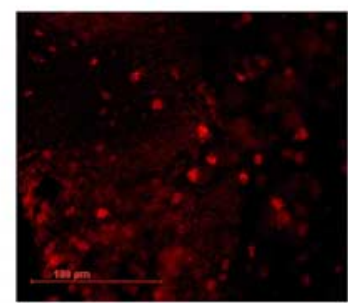

CB2

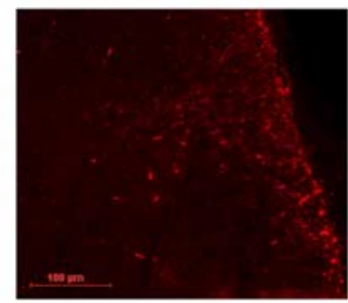

CB2
B
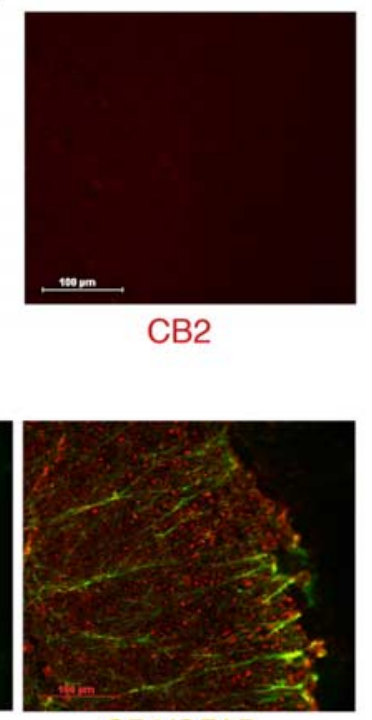

CB2/GFAP

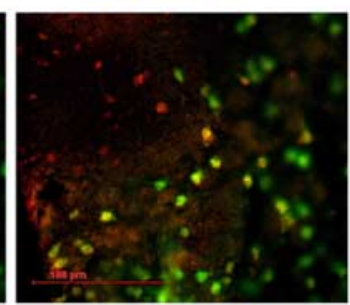

CB2/Neu-N

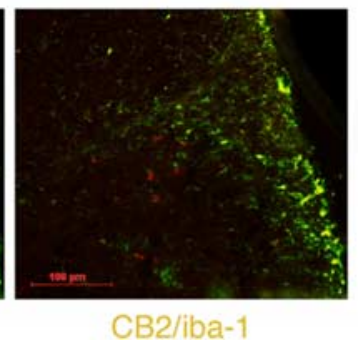

Figure 3. $\quad \mathrm{CB}_{2}$ expression and colocalization in male transgenic mice overexpressing $C B_{2}$ receptors. $A$, Relative abundance of endogenous and transgenic $C_{2}$ RNA in PAG, thalamus, cervical spinal cord, and thoracic spinal cord of transgenic mice was determined by real-time $P C R$ quantification. After being analyzed using the $\Delta \mathrm{Ct}$ method, data were normalized to GAPDH expression. The group with the lower value was assigned a value of 1 . Thestars represent differences in relative transcriptabundance between endogenous and transgenic $C_{2}$ receptor (one-way repeated-measures $A N O V A$ ). Error bars indicate $S E M$. $B$, Negative immunostaining for $C_{2}$ receptor in the lumbar spinal cord of $\mathrm{CB}_{2}{ }^{-1-}$ mice that serves as a control for $\mathrm{CB}_{2}$ staining in transgenic mice overexpressing $\mathrm{CB}_{2}$ receptors. $C$, Doublefluorescence immunostaining for $\mathrm{CB}_{2}$ receptor, GFAP (astrocyte), Neu-N (neuron), and iba-1 (microglia) in lumbar spinal cord sections from transgenic mice overexpressing $\mathrm{CB}_{2}$ receptors. First plot, Immunostaining for $\mathrm{CB}_{2}$ receptor (red; $C Y 3$ anti-rabbit) and for astrocyte marker GFAP (green; FITC anti-rabbit). Second plot, Same staining for $\mathrm{CB}_{2}$ receptor (red; $\mathrm{CY} 3$ anti-rabbit) and for neuron (fluorescein-conjugated Neu-N). Third plot, Same staining for $\mathrm{CB}_{2}$ receptor (red; $\mathrm{CY}_{3}$ anti-rabbit) and for microglial marker iba-1 (green; FITC anti-rabbit).

\section{Neuropathic pain is attenuated in transgenic mice overexpressing $\mathrm{CB}_{2}$ cannabinoid receptors}

The manifestations of neuropathic pain induced by sciatic nerve injury were also evaluated in transgenic mice overexpressing $\mathrm{CB}_{2}$ cannabinoid receptors. These transgenic mice were generated by using a murine PrP promoter that is specifically expressed in neurons and glial cells (Castilla et al., 2005). We obtained five different transgenic lines. Three transgenic lines were selected by evaluation of the transgenic $\mathrm{CB}_{2}$ receptor in different regions of the brain (data not shown). One of these lines with high expression of transgenic $\mathrm{CB}_{2}$ receptor in the spinal cord was selected for the present experiments. The expression of $\mathrm{CB}_{2}$ mRNA was eval- uated in several central structures related to pain transmission in these mice by realtime PCR. The expression of $\mathrm{CB}_{2}$ receptors was mainly enhanced in transgenic mice at the level of the spinal cord $(205 \%$ at the cervical level and $176 \%$ at the thoracic level), although a clear enhancement was also observed in supraspinal structures involved in pain transmission, such as the thalamus $(95 \%)$ and the periaqueductal gray matter (56\%) (Fig. 3A). The different expression observed in spinal cord, thalamus, and periaqueductal gray matter was attributable to the murine PrP promoter used in the transgene construct. To delineate the cell types expressing $\mathrm{CB}_{2}$ receptors, we performed an immunofluorescence analysis of spinal cord sections of transgenic mice overexpressing $\mathrm{CB}_{2}$ receptors. We found that $\mathrm{CB}_{2}$ receptors colocalize with the microglia marker ibal and with the neuronal marker Neu-N, but not with the astrocyte marker GFAP (Fig. $3 B$ ). In agreement with the previous experiment, baseline responses of transgenic mice overexpressing $\mathrm{CB}_{2}$ receptors and $\mathrm{CB}_{2}{ }^{+/+}$littermates were similar in the three nociceptive models, and sham operation did not produce any modification in the nociceptive thresholds. Thermal hyperalgesia and mechanical and thermal allodynia induced by sciatic nerve injury in the ipsilateral paw in $\mathrm{CB}_{2}{ }^{+/+}$mice were all strongly attenuated in transgenic mice overexpressing $\mathrm{CB}_{2}$ receptors (Fig. 4). No mirror image of pain was revealed in any experimental group. A similar result was observed in both genders of transgenic mice overexpressing $\mathrm{CB}_{2}$ receptors on the three nociceptive models (supplemental Fig. 2, available at www.jneurosci.org as supplemental material). Sciatic nerve injury robustly enhanced the microglial response in the ipsilateral horn of the spinal cord in $\mathrm{CB}_{2}{ }^{+/+}$mice, indicated by a significant increase of ibal staining (Fig. 5A,B). The enhanced ibal staining was attributable to an increased number of microglia, with an activated phenotype. This response was significantly attenuated in transgenic mice overexpressing $\mathrm{CB}_{2}$ receptors. Microglial staining was not significantly modified in the contralateral horn in these groups of mice. Astrocytic staining was also significantly enhanced in the ipsilateral horn of the spinal cord in $\mathrm{CB}_{2}{ }^{+/+}$mice, but not in transgenic animals overexpressing $\mathrm{CB}_{2}$ receptors nor in the contralateral side in any experimental group (Fig. 5A,B).

Sciatic nerve injury in $\mathrm{CB}_{2}{ }^{+/+} / \mathrm{CB}_{2}{ }^{-/-}$bone marrow chimeric mice produced similar development of neuropathic pain as in $\mathrm{CB}_{2}{ }^{-1-}$ mice

We have finally evaluated in vivo the involvement of the immune system in the responses observed in $\mathrm{CB}_{2}{ }^{-1-}$ mice. For this pur- 
A

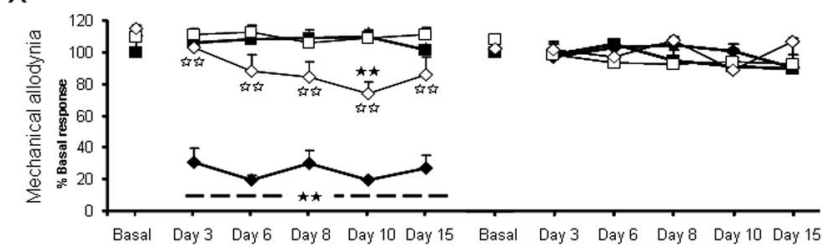

B

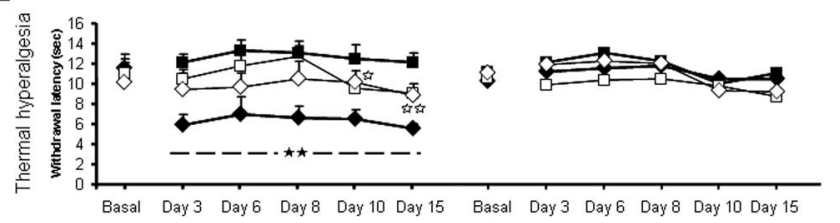

C

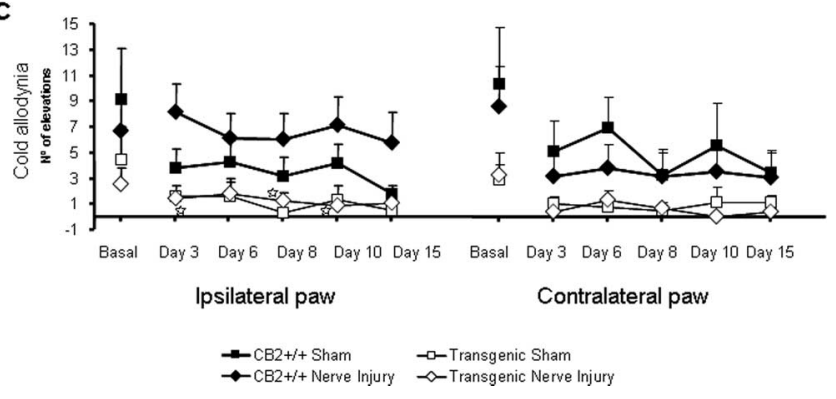

Figure 4. Behavioral manifestations of neuropathic pain in male transgenic mice overexpressing $\mathrm{CB}_{2}$ receptors. Development of neuropathic pain in male transgenic mice overexpressing $\mathrm{CB}_{2}$ receptors $(n=12)$ and wild-type mice $(n=12)$. A single tight ligature around onethird or one-half of sciatic nerve was made to induce the neuropathic pain. Mice were tested in the ipsilateral and contralateral paw for evaluating mechanical allodynia (von Frey model percentage of the basal $\mathrm{CB}_{2}{ }^{+/+}$sham-operated values) $(\boldsymbol{A})$, thermal hyperalgesia (plantar test; withdrawal latency in seconds) $(\boldsymbol{B})$, and cold allodynia (cold-plate test; number of paw elevations) (C) on days 3, 6, 8, 10, and 15 after surgery. The black stars represent comparison between sciatic nerve injury and sham-operated animals. The white stars represent comparison between genotypes. One star, $p<0.05$; two stars, $p<0.01$. Error bars indicate SEM.

pose, we have replicated the phenotype of these knock-outs in irradiated $\mathrm{CB}_{2}{ }^{+/+}$mice reconstituted with $\mathrm{BM}$ cells from $\mathrm{CB}_{2}{ }^{-1-}$ mice (chimera- $\mathrm{CB}_{2}$ ). $\mathrm{BM}$ cells from $\mathrm{CB}_{2}{ }^{-1-}$ donor mice expressing the surface antigen CD45.2 were intravenously injected into lethally irradiated CD45.1 congenic recipients. After 8 weeks of engraftment, efficient reconstitution of recipient chimeric mice was verified by peripheral blood lymphocytes analysis (Fig. $6 A, B$ ). Irradiated $\mathrm{CB}_{2}{ }^{+/+}$mice transplanted with $\mathrm{CB}_{2}{ }^{+/+}$ $\mathrm{BM}$ cells served as controls (chimera-WT). Flow cytometry analysis of spinal cord tissues $14 \mathrm{~d}$ after surgery revealed a massive recruitment of donor-derived microglia. Baseline nociceptive responses were similar in all the experimental groups, and sham operation did not modify these basal nociceptive thresholds (Fig. 6 , Table 1). Sciatic nerve injury in BM-chimeric mice produced a similar mechanical allodynia and thermal hyperalgesia in the ipsilateral paw as was observed in $\mathrm{CB}_{2}{ }^{+/+}$and $\mathrm{CB}_{2}{ }^{-/-}$animals (Fig. 6C, Table 1). However, mechanical and thermal allodynia on the contralateral side was only present in the chimera- $\mathrm{CB}_{2}$ mice (constituted $\mathrm{CB}_{2}{ }^{-1-}$ bone marrow cells) and in $\mathrm{CB}_{2}^{-1-}$ mice. Therefore, chimera- $\mathrm{CB}_{2}$ mice developed the same enhanced manifestations of neuropathic pain as $\mathrm{CB}_{2}{ }^{-1-}$ animals in the previous experiment. In contrast, chimera-WT animals did not show contralateral allodynia, and thus neuropathic pain of these reconstituted animals did not differ from normal $\mathrm{CB}_{2}{ }^{+/+}$ mice (Fig. 6C). Microglial cell activation induced by sciatic nerve injury was evaluated by using immunofluorescence of ibal. A similar enhancement was observed in the ipsilateral and con- tralateral horn of the spinal cord in chimeric mice. A significant increase of the ibal staining of activated microglia was observed in the ipsilateral and contralateral side after nerve injury in chimera- $\mathrm{CB}_{2}$ mice. Astrocytic staining was also significantly enhanced in both ipsilateral and contralateral horns of the spinal cord in chimeric $\mathrm{CB}_{2}$ mice (Fig. $7 A, B$ ).

\section{Discussion}

The present results reveal a crucial role of the $\mathrm{CB}_{2}$ cannabinoid receptors in controlling the development of neuropathic pain through an immune mechanism linked to glial activation. Hyperalgesia and allodynia induced by sciatic nerve injury were enhanced in $\mathrm{CB}_{2}{ }^{-1-}$ mice, as revealed by a mirror image of pain in the contralateral side. These behavioral manifestations of neuropathic pain matched the changes induced in microglial and astrocyte activation. In agreement, a reduced manifestation of neuropathic pain after nerve injury was observed in transgenic mice overexpressing $\mathrm{CB}_{2}$ receptors under the control of a PrP promoter in the brain and the spinal cord. Expression of transgenic $\mathrm{CB}_{2}$ receptors was pronounced in microglial cells and neurons, but absent in astrocytes, in agreement with the literature (Van Sickle et al., 2005; Romero-Sandoval et al., 2008). Decreased hyperalgesia, allodynia, and spinal glial activation in these transgenic mice could be related to the strong overexpression of $\mathrm{CB}_{2}$ receptors at the level of the spinal cord. However, these mice also showed an enhanced expression of $\mathrm{CB}_{2}$ receptors in supraspinal structures involved in pain transmission, such as the thalamus and the periaqueductal gray matter, which could also participate in the decreased manifestations of neuropathic pain. The opposite phenotype revealed in transgenic mice overexpressing $\mathrm{CB}_{2}$ receptors and $\mathrm{CB}_{2}{ }^{-1-}$ mice underlines the relevance of these receptors in mediating the manifestations of neuropathic pain. Similar baseline responses were obtained in the different lines of genetically modified mice lacking or overexpressing $\mathrm{CB}_{2}$ receptors, indicating the absence of nociceptive changes under physiological conditions in these animals. These results suggest that the activation of $\mathrm{CB}_{2}$ receptors could attenuate the manifestations of neuropathic pain at lower doses than those required to induce antinociception.

The altered manifestations of neuropathic pain observed in $\mathrm{CB}_{2}{ }^{-1-}$ mice and transgenic mice overexpressing $\mathrm{CB}_{2}$ receptors suggest that endocannabinoids play an important role in the control of pain under these pathological conditions. In support of this hypothesis, an enhancement in the levels of the two main endocannabinoids, anandamide and 2-arachidonoyl-glycerol, was revealed after sciatic nerve injury in the spinal cord and several brain areas involved in pain, such as the periaqueductal gray matter and the rostral ventral medulla (Petrosino et al., 2007). The endocannabinoid levels were also enhanced after sciatic nerve injury in the dorsal root ganglia (Mitrirattanakul et al., 2006) and the section of the sciatic nerve proximal to the lesion (Agarwal et al., 2007). These increased endocannabinoid levels are likely related to enhanced biosynthesis or decreased catabolism and transport because endocannabinoids are produced on demand without any substantial storage (Di Marzo, 1998). Therefore, endocannabinoids could produce a tonic activation of $\mathrm{CB}_{2}$ receptors after sciatic nerve injury that would limit the progression and manifestations of neuropathic pain. In agreement, both mechanical and thermal hyperalgesia produced after sciatic nerve injury were attenuated by the administration of $\mathrm{N}$-arachidonoyl-serotonin, an inhibitor of fatty acid amide hydrolase, the enzyme responsible of the degradation of anandam- 
A

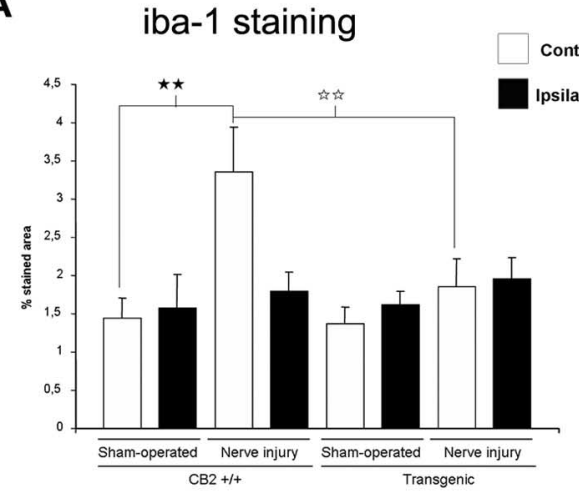

B

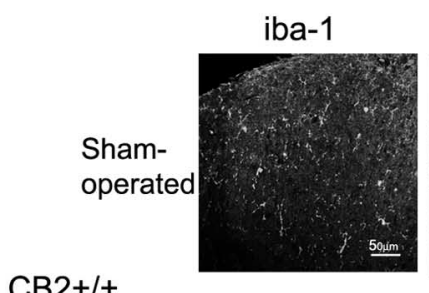

$\mathrm{CB} 2+/+$

Nerve injury
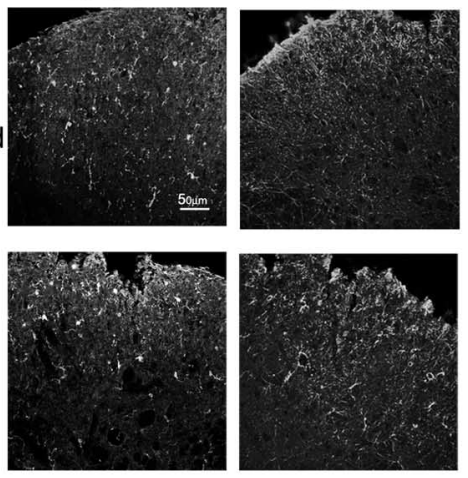

Transgenic
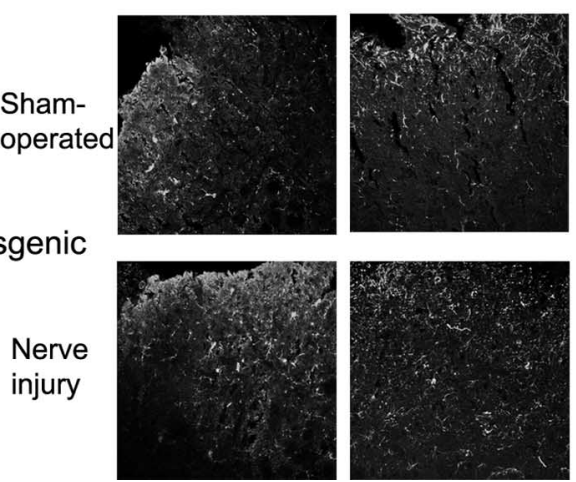

GFAP staining

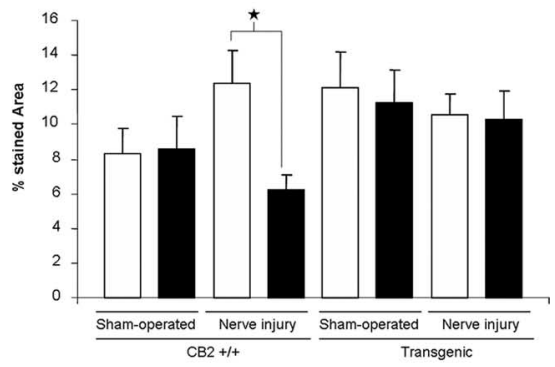

Contralateral
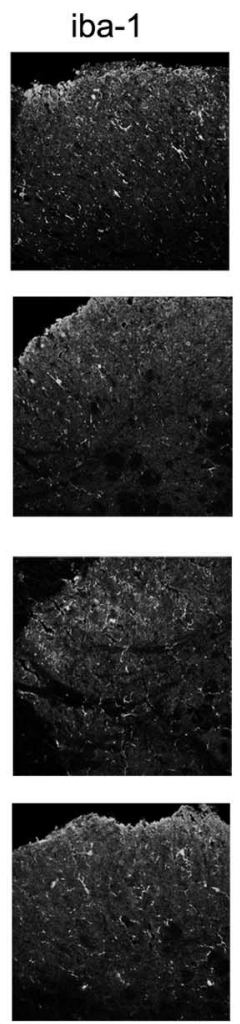

Figure 5. Expression of glial activation in spinal cord of $\mathrm{CB}_{2}^{+/+}$and transgenic mice overexpressing $\mathrm{CB}_{2}$ receptors. $A$, The increase of microglia and astrocytic response in dorsal horn of lumbar spinal cord after sciatic nerve injury is only observed in $\mathrm{CB}_{2}{ }^{+/+}$mice. Iba- 1 staining (microglia) ( $n=4$ per group) and GFAP staining (astrocytes) $(n=4$ per group) were visualized with $\mathrm{CY} 3$ anti-rabbit (red). Ipsilateral dorsal horns were represented with white bars, and contralateral dorsal horns were represented with black bars. Data are expressed as percentage of stained area. Error bars indicate SEM. The black stars represent comparisons between sham-operated and nerve injury or between ipsilateral and contralateral paw. The white stars represent comparisons between genotypes. One star, $p<0.05$; two stars, $p<0.01$. B, Representative confocal images of the immunostaining of iba- 1 (microglia) and GFAP (astrocyte) in lumbar dorsal horn of $\mathrm{CB}_{2}{ }^{+++}$and transgenic mice overexpressing $\mathrm{CB}_{2}$ receptors recorded with the $40 \times$ objective.

ide (Maione et al., 2007), which further support the role of endocannabinoids in the control of neuropathic pain.

$\mathrm{CB}_{2}$ receptors are present in microglial cells (RomeroSandoval et al., 2008) and neurons (Van Sickle et al., 2005). However, the possible presence of $\mathrm{CB}_{2}$ receptors in neurons and its possible functional role is still a controversial issue that requires additional investigation. In the spinal cord, $\mathrm{CB}_{2}$ receptor expression is associated with the appearance of activated microglial cells after chronic pain produced by peripheral nerve injury (Zhang et al., 2003). Glial activation has proinflammatory actions (Watkins
GFAP
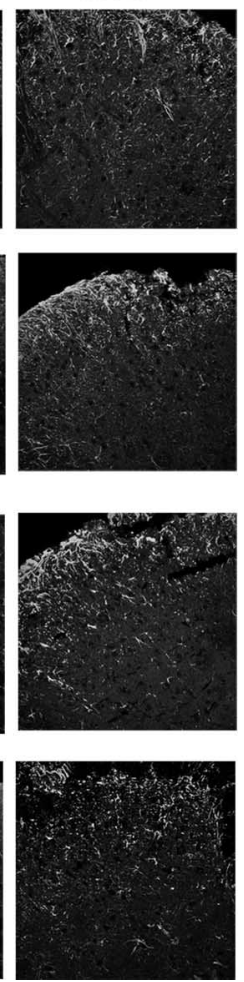

et al., 2003), and although it is not involved in acute pain (Raghavendra et al., 2003), its activation is required for the induction and development of chronic pain states (Raghavendra et al., 2003; Watkins et al., 2003). Thus, microglia activation is involved in the development of neuropathic pain through the release of several cytokines that are known to produce neuronal sensitization in the spinal cord (DeLeo and Yezierski, 2001; Clark et al., 2007) and initiate the neuroinflammatory process leading to the development of neuropathic pain (Watkins et al., 2001). The chemical modulators that activate microglial cells are under the control of immune mediators, as well as neuromodulators released by nearby neurons, such as prostaglandins (Tanga et al., 2006). IFN- $\gamma$ (interferon- $\gamma$ ) is another mediator involved in microglia activation that can induce an upregulation of $\mathrm{CB}_{2}$ mRNA expression (Carlisle et al., 2002). The complete neuroinflammatory process leading to the progression of the neuropathic pain requires the coactivation of both microglia and astrocytes (Colburn et al., 1999). Cytokines that are released by the activated microglia, such as IL- $1 \beta$ (interleukin-1 $\beta$ ), can be responsible for the subsequent activation of astrocytes, which permits the consolidation of the neuropathic pain state (John et al., 2004).

Interestingly, $\mathrm{CB}_{2}$ receptor stimulation has been reported to attenuate microglial activation (Ehrhart et al., 2005; RomeroSandoval and Eisenach, 2007) and the release of cytokines by the activated microglia (Puffenbarger et al., 2000; Klegeris et al., 2003; Sheng et al., 2005). In agreement, $\mathrm{CB}_{2}$ agonists produce analgesic effects (Ibrahim et al., 2005; Beltramo et al., 2006) (for review, see Guindon and Hohmann, 2008) and reduce activated microglia in neuropathic pain models (RomeroSandoval et al., 2008).

$\mathrm{CB}_{2}$ receptors located on microglial cells would play a crucial role in limiting the spreading of this neuroinflammatory process. Thus, the activity of $\mathrm{CB}_{2}$ receptors in microglial cells would reduce its activation during the development of neuropathic pain and the consequent release of proinflammatory cytokines. In the absence of $\mathrm{CB}_{2}$ receptors, a more widespread activation of microglial cells occurs after sciatic nerve injury, which would lead to an enhancement in the manifestations of neuropathic pain and to the presence of a mirror image of pain in the contralateral side.

An alteration of the central immune responses after nerve injury could be responsible for the enhanced manifestations of the neuropathic pain in $\mathrm{CB}_{2}{ }^{-1-}$ mice. This hypothesis was demonstrated by replicating the enhanced behavioral and histological manifestations of neuropathic pain observed in $\mathrm{CB}_{2}{ }^{-1-}$ mice in irradiated $\mathrm{CB}_{2}{ }^{+/+}$mice transplanted with bone marrow cells 
from $\mathrm{CB}_{2}{ }^{-1-}$. These $\mathrm{CB}_{2}{ }^{-1-} \mathrm{BM}$ chimeric mice showed enhanced manifestations of neuropathic pain as revealed by allodynia, hyperalgesia, and astrocytic and microglial cell activation in the contralateral side of the spinal cord after sciatic nerve injury. By generating bone marrow-chimeric mice, we present evidence that newly recruited monocytes from the bone marrow of $\mathrm{CB}_{2}$ deficient mice participate in the reconstitution of spinal cord microglia after peripheral nerve injury.

Recently, it has been demonstrated that bone marrow-derived cells that are recruited to the spinal cord are implicated in the development of neuropathic pain. In particular, CCR2 expression in either resident microglia or bone marrow-derived macrophages may be sufficient for the development of mechanical allodynia in a murine neuropathic pain model (Zhang et al., 2007). Subsequent to nerve injury, gradients formed by chemokine ligand 2 (CCL2) and CCL3 orchestrate the recruitment and activation of resident and monocyte-derived microglia via signaling through their respective receptors CCR2, CCR1, and CCR5 (Scholz and Woolf, 2007). $\mathrm{CB}_{2}$ cannabinoid receptor activity may critically influence the induction of CCR2 expression by monocytes and thus inhibit their chemotaxis (Steffens et al., 2005). Moreover, endocannabinoids were found to abolish microglia activation by inhibiting NO (nitric oxide) release through a mechanism linked to the MAPK (mitogen-activated protein kinase) pathway (Eljaschewitsch et al., 2006). Therefore, our findings demonstrate a crucial role of the immune response mediated by microglia in the development of increased neuropathic pain sensitivity in the $\mathrm{CB}_{2}{ }^{-/-}$ animals. A direct action on peripheral $\mathrm{CB}_{2}$ receptors located in primary afferent neurons (Wotherspoon et al., 2005; Beltramo et al., 2006) and in keratinocytes involved in the release of $\beta$-endorphins (Ibrahim et al., 2005) has been reported to be involved in the analgesic responses of $\mathrm{CB}_{2}$ agonist. However, these peripheral effects of $\mathrm{CB}_{2}$ receptors do not seem to be involved in the enhanced manifestations of neuropathic pain observed in the present study in $\mathrm{CB}_{2}$ knock-out mice.

Mice genetically modified either by increasing or eliminating specific gene may be limited by the fact that this genetic change may be affecting not only the target gene but also other biological components, perhaps participating in the effects evaluated in these genetic models. Therefore, pharmacological studies using selective ligands of $\mathrm{CB}_{2}$ receptors would be use-
A

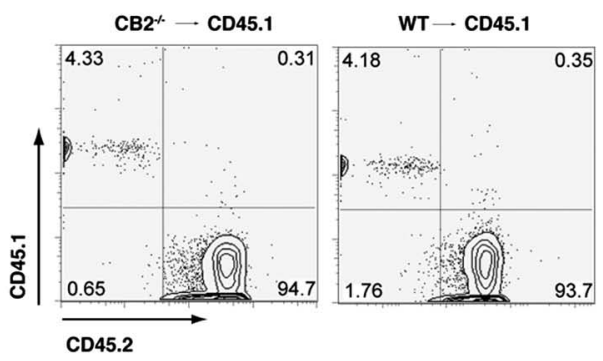

B
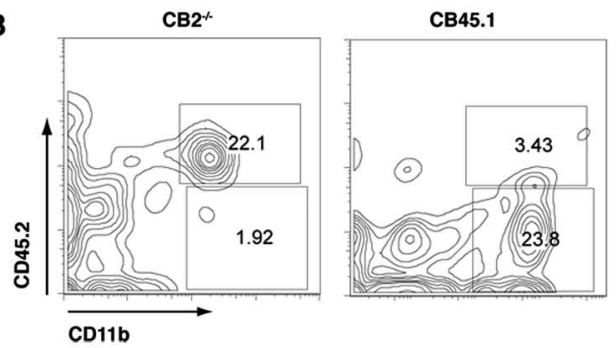

CB2 - CD45.1

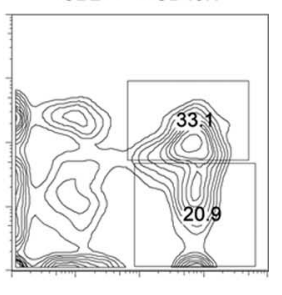

C
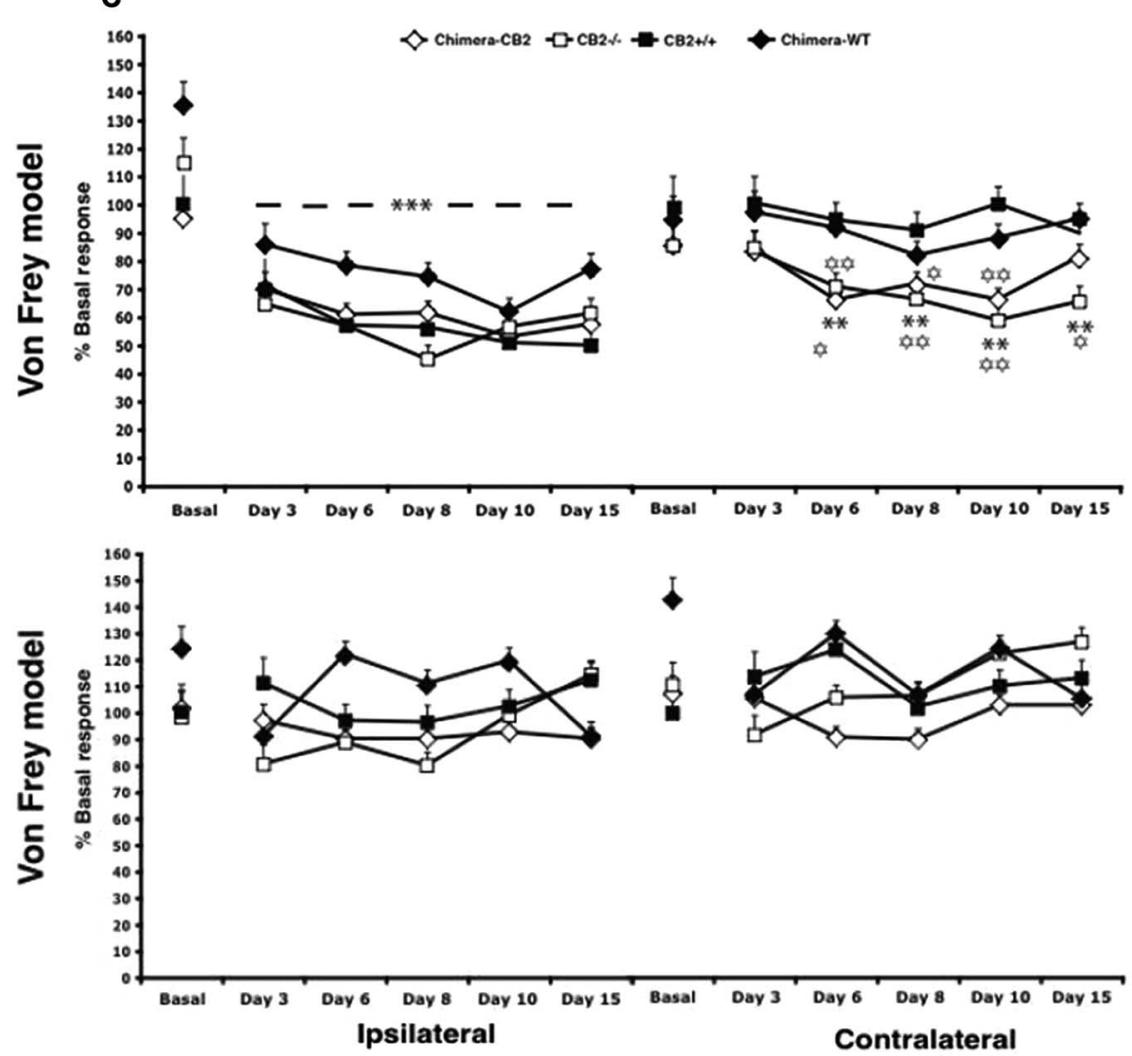

Figure 6. Reconstitution efficiency of $B M$ chimeric mice and behavioral manifestations of neuropathic pain after transplantation of $B M$ cells lacking $\mathrm{CB}_{2}$ receptors in irradiated $\mathrm{CB}_{2}{ }^{+/+}$mice. $A$, Lethally irradiated recipient mice (CD45.1) were reconstituted with $\mathrm{BM}$ from $\mathrm{CB}_{2}{ }^{-1-}$ (left) or WT (right) animals expressing the congenic marker CD45.2. Flow cytometry of peripheral blood lymphocytes of BM chimeric mice was performed 8 weeks later by staining with anti-CD45.1 and -CD45.2 antibodies. Frequencies of CD45.2 donor-derived and CD45.1 recipient-derived cells are indicated in each quadrant. $\boldsymbol{B}$, Presence of $\mathrm{CB}_{2}$-derived microglia in the spinal cord of BM-chimeric mice $14 \mathrm{~d}$ after surgery. Representative flow cytometry demonstrating $\mathrm{CD} 45.2^{+} \mathrm{CD} 11 \mathrm{~b}^{+}$cells in the spinal cord of $\mathrm{CB}_{2}{ }^{-1-}(\mathrm{CD} 45.2)$ control mice (left) and lethally irradiated $\mathrm{CD} 45.1$ congenic recipients after engraftment with $\mathrm{CB}_{2}{ }^{-1-} \mathrm{BM}$ cells (chimera- $\mathrm{CB}_{2}$ ) (right). $\mathrm{CD}_{11 b^{+}}$cells in the spinal cord of $\mathrm{CD} 45.1$ control mice (middle) are negative for the congenic marker $\mathrm{CD} 45.2$. Representative dot blots are shown. $C$, The following groups were studied: $\mathrm{CB}_{2}{ }^{-1-}$ and $\mathrm{CB}_{2}{ }^{+/+}$control animals, chimera- $\mathrm{CB}_{2}\left(\mathrm{CB}_{2}{ }^{+/+}\right.$mice receiving bone marrow from $\mathrm{CB}_{2}{ }^{-1-}$ animals), and chimera-WT $\left(\mathrm{CB}_{2}{ }^{+/+}\right.$mice receiving bone marrow from $\mathrm{CB}_{2}{ }^{+/+}$mice). Development of neuropathic pain in $\mathrm{CB}_{2}{ }^{+/+}(n=10), \mathrm{CB}_{2}{ }^{-1-}(n=10)$, chimera-WT $(n=$ $8)$, and chimera- $\mathrm{CB}_{2}(n=12)$. Mechanical allodynia after partial sciatic nerve ligation was tested in the ipsilateral and contralateral paws on day $3,6,8,10$, and 15 after the surgery. The withdrawal thresholds are presented as percentage of the basal $\mathrm{CB}_{2}{ }^{+/+}$ values. Error bars indicate SEM. The black stars represent comparison between sciatic nerve injury and sham-operated animals. The white stars represent comparison between genotypes. One star, $p<0.05$; two stars, $p<0.01$. 
Table 1. Behavioral manifestations of neuropathic pain after transplantation of bone marrow cells lacking $\mathrm{CB}_{2}$ receptors in irradiated $\mathrm{CB}_{2}{ }^{+/+}$mice

\begin{tabular}{|c|c|c|c|c|c|c|}
\hline & Basal & Day 3 & Day 6 & Day 8 & Day 10 & Day 15 \\
\hline \multicolumn{7}{|l|}{ Contralateral side } \\
\hline \multicolumn{7}{|l|}{ PNL } \\
\hline Chimera- $\mathrm{CB}_{2}$ & $6.8 \pm 0.52$ & $5.7 \pm 0.52$ & $6.1 \pm 0.58$ & $5.3 \pm 0.52^{*}$ & $5.8 \pm 0.8$ & $5.1 \pm 0.55^{*}$ \\
\hline $\mathrm{CB}_{2}^{-1-}$ & $4.1 \pm 0.2$ & $4 \pm 0.26$ & $3.5 \pm 0.26$ & $3.2 \pm 0.26^{*}$ & $3.26 \pm 0.26^{*}$ & $3.3 \pm 0.26^{*}$ \\
\hline $\mathrm{CB}_{2}^{+/+}$ & $4.7 \pm 0.3$ & $4.4 \pm 0.32$ & $4.1 \pm 0.33$ & $4.9 \pm 0.3$ & $5.2 \pm 0.3$ & $4.7 \pm 0.3$ \\
\hline Chimera-WT & $5.6 \pm 0.48$ & $4.2 \pm 0.48$ & $5.2 \pm 0.48$ & $5.4 \pm 0.48$ & $5.4 \pm 0.47$ & $4.2 \pm 0.48$ \\
\hline \multicolumn{7}{|l|}{ Sham } \\
\hline Chimera- $\mathrm{CB}_{2}$ & $6.2 \pm 0.69$ & $6.2 \pm 0.69$ & $6.9 \pm 0.7$ & $6.1 \pm 0.36$ & $7.2 \pm 0.66$ & $6.5 \pm 0.46$ \\
\hline $\mathrm{CB}_{2}^{-1-}$ & $4.2 \pm 0.68$ & $3.8 \pm 0.8$ & $4.4 \pm 0.83$ & $4.22 \pm 0.44$ & $4.45 \pm 0.78$ & $4.68 \pm 0.54$ \\
\hline $\mathrm{CB}_{2}^{+1+}$ & $5.35 \pm 0.76$ & $4.2 \pm 0.91$ & $5.4 \pm 0.92$ & $4.3 \pm 0.48$ & $4.7 \pm 0.88$ & $4.5 \pm 0.6$ \\
\hline Chimera-WT & $4.4 \pm 0.62$ & $4.2 \pm 0.91$ & $5.15 \pm 0.75$ & $5.4 \pm 0.39$ & $5.4 \pm 0.72$ & $5.1 \pm 0.49$ \\
\hline \multicolumn{7}{|l|}{ Ipsilateral side } \\
\hline \multicolumn{7}{|l|}{ PNL } \\
\hline Chimera- $\mathrm{CB}_{2}$ & $6.5 \pm 0.43$ & $5.15 \pm 0.42^{*}$ & $5.6 \pm 0.39^{*}$ & $4.01 \pm 0.28^{*}$ & $4.1 \pm 0.37^{*}$ & $3.47 \pm 0.29^{*}$ \\
\hline $\mathrm{CB}_{2}^{-1-}$ & $3.74 \pm 0.5$ & $2.8 \pm 0.4^{*}$ & $2.03 \pm 0.46^{*}$ & $2.4 \pm 0.321^{*}$ & $2.54 \pm 0.43^{*}$ & $2.88 \pm 0.34^{*}$ \\
\hline $\mathrm{CB}_{2}^{+1+}$ & $5 \pm 0.45$ & $2.58 \pm 0.44^{*}$ & $2.3 \pm 0.42^{*}$ & $2.84 \pm 0.29^{*}$ & $2.55 \pm 0.38^{*}$ & $2.59 \pm 0.3^{*}$ \\
\hline Chimera-WT & $5.66 \pm 0.5$ & $3.23 \pm 0.49^{*}$ & $3.6 \pm 0.46^{*}$ & $3.6 \pm 0.32^{*}$ & $3.32 \pm 0.43^{*}$ & $2.6 \pm 0.34^{*}$ \\
\hline \multicolumn{7}{|l|}{ Sham } \\
\hline Chimera- $\mathrm{CB}_{2}$ & $6.3 \pm 0.53$ & $5.6 \pm 0.52$ & $6 \pm 0.34$ & $6.1 \pm 0.34$ & $7.1 \pm 0.47$ & $6.2 \pm 0.37$ \\
\hline $\mathrm{CB}_{2}^{-1-}$ & $4.1 \pm 0.63$ & $3.8 \pm 0.62$ & $4.03 \pm 0.59$ & $4.44 \pm 0.41$ & $4.33 \pm 0.54$ & $4.5 \pm 0.43$ \\
\hline $\mathrm{CB}_{2}^{+1+}$ & $4.8 \pm 0.71$ & $3.8 \pm 0.69$ & $4.02 \pm 0.66$ & $4.08 \pm 0.46$ & $4.51 \pm 0.63$ & $3.9 \pm 0.48$ \\
\hline Chimera-WT & $4.6 \pm 0.58$ & $4.1 \pm 0.56$ & $5.5 \pm 0.53$ & $5.1 \pm 0.38$ & $5.4 \pm 0.5$ & $5.4 \pm 0.39$ \\
\hline
\end{tabular}

Development of neuropathic pain in male $\mathrm{CB}_{2}^{+1+}(n=10), \mathrm{CB}_{2}^{-l-}(n=10)$, chimera-WT $(n=8)$, and chimera- $\mathrm{CB}_{2}(n=12)$ mice. Thermal hyperalgesia after partial sciatic nerve ligation (PNL) was tested in the ipsilateral and contralateral paws on days $3,6,8,10$, and 15 after the surgery. Data were compared separately at the ipsilateral and contralateral side by $A N O V A$. $\mathrm{CB}_{2}{ }^{-1-}$ and chimera- $\mathrm{CB}_{2}$ mice developed allodynia on the contralateral side, but not $\mathrm{CB}_{2}{ }^{+/+}$ or chimera-WT. The asterisks represent comparison between base values and the values measured at different time points.

ful to confirm the relevance of the present results. Nevertheless, these genetic manipulations have been considered a key approach to the identification of alterations associated to different pathological conditions and to the discovering of new potential therapeutic targets in a variety of neuropsychiatric disorders. In this study, the use of different lines of genetically modified mice and the according results obtained in all these lines further support the relevance of the findings.

Our findings reveal a crucial role of the $\mathrm{CB}_{2}$ receptor in the modulation of the immune response of the nervous system during neuropathic pain. In contrast, the genetic disruption of the $\mathrm{CB}_{1}$ receptor had no major consequences on the development of neuropathic pain (Castañé et al., 2006) despite the high expression of these receptors in the CNS (Tsou et al., 1998). Only $\mathrm{CB}_{1}$ receptors expressed in peripheral nociceptors but not in the CNS seem to be involved in the manifestations of neuropathic pain (Agarwal et al., 2007). The selective involvement of $\mathrm{CB}_{2}$ receptors and the low expression in neurons (Van Sickle et al., 2005) further emphasize the relevance of these receptors in the central adaptive mechanisms leading to neuropathic pain. Therefore, $\mathrm{CB}_{2}$ cannabinoid agonists could represent a new group of pharmacological agents for the treatment of neuropathic pain devoid of any psychoactive side effects.

\section{References}

Agarwal N, Pacher P, Tegeder I, Amaya F, Constantin CE, Brenner GJ, Rubino T, Michalski CW, Marsicano G, Monory K, Mackie K, Marian C, Batkai S, Parolaro D, Fischer MJ, Reeh P, Kunos G, Kress M, Lutz B, Woolf CJ, et al. (2007) Cannabinoids mediate analgesia largely via peripheral type 1 cannabinoid receptors in nociceptors. Nat Neurosci 10:870-879.

Beltramo M, Bernardini N, Bertorelli R, Campanella M, Nicolussi E, Fredduzzi S, Reggiani A (2006) CB2 receptor-mediated antihyperalgesia: possible direct involvement of neural mechanisms. Eur J Neurosci 23:1530-1538.

Bingham B, Jones PG, Uveges AJ, Kotnis S, Lu P, Smith VA, Sun SC, Resnick L, Chlenov M, He Y, Strassle BW, Cummons TA, Piesla MJ, Harrison JE, Whiteside GT, Kennedy JD (2007) Species-specific in vitro pharmaco- logical effects of the cannabinoid receptor 2 (CB2) selective ligand AM1241 and its resolved enantiomers. Br J Pharmacol 151:1061-1070.

Buckley NE, McCoy KL, Mezey E, Bonner T, Zimmer A, Felder CC, Glass M, Zimmer A (2000) Immunomodulation by cannabinoids is absent in mice deficient for the cannabinoid $\mathrm{CB}(2)$ receptor. Eur J Pharmacol 396:141-149.

Carlisle SJ, Marciano-Cabral F, Staab A, Ludwick C, Cabral GA (2002) Differential expression of the CB2 cannabinoid receptor by rodent macrophages and macrophage-like cells in relation to cell activation. Int Immunopharmacol 2:69-82.

Castañé A, Célérier E, Martín M, Ledent C, Parmentier M, Maldonado R, Valverde O (2006) Development and expression of neuropathic pain in CB1 knockout mice. Neuropharmacology 50:111-122.

Castilla J, Gutiérrez-Adán A, Brun A, Pintado B, Salguero FJ, Parra B, Segundo FD, Ramirez MA, Rabano A, Cano MJ, Torres JM (2005) Transgenic mice expressing bovine $\operatorname{PrP}$ with a four extra repeat octapeptide insert mutation show a spontaneous, non-transmissible, neurodegenerative disease and an expedited course of BSE infection. FEBS Lett 579:237-6246.

Chaplan SR, Bach FW, Pogrel JW, Chung JM, Yaksh TL (1994) Quantitative assessment of tactile allodynia in the rat paw. J Neurosci Methods 53:55-63.

Clark AK, Yip PK, Grist J, Gentry C, Staniland AA, Marchand F, Dehvari M, Wotherspoon G, Winter J, Ullah J, Bevan S, Malcangio M (2007) Inhibition of spinal microglial cathepsin $S$ for the reversal of neuropathic pain. Proc Natl Acad Sci U S A 104:10655-10660.

Colburn RW, Rickman AJ, DeLeo JA (1999) The effect of site and type of nerve injury on spinal glial activation and neuropathic pain behavior. Exp Neurol 157:289-304.

DeLeo JA, Yezierski RP (2001) The role of neuroinflammation and neuroimmune activation in persistent pain. Pain 90:1-6.

Di Marzo V (1998) Endocannabinoids and other fatty acid derivates with cannabimimetic properties: biochemistry and possible physiopathological relevance. Biochim Biophys Acta 1392:153-175.

Ehrhart J, Obregon D, Mori T, Hou H, Sun N, Bai Y, Klein T, Fernandez F, Tan J, Shytle RD (2005) Stimulation of cannabinoid receptor 2 (CB2) suppresses microglial activation. J Neuroinflammation 2:29.

Eljaschewitsch E, Witting A, Mawrin C, Lee T, Schmidt PM, Wolf S, Hoertnagl H, Raine CS, Schneider-Stock R, Nitsch R, Ullrich O (2006) The endocannabinoid anandamide protects neurons during CNS inflammation by induction of MKP-1 in microglial cells. Neuron 49:67-79. 
Giblin GM, O'Shaughnessy CT, Naylor A, Mitchell WL, Eatherton AJ, Slingsby BP, Rawlings DA, Goldsmith P, Brown AJ, Haslam CP, Clayton NM, Wilson AW, Chessell IP, Wittington AR, Green R (2007) Discovery of 2-[(2,4-dichlorophenyl)amino]- $N$ - [(tetrahydro-2 $H$-pyran-4-yl) methyl]-4-(trifluoromethyl)-5-pyrimidinecarboxamide, a selective CB2 receptor agonist for the treatment of inflammatory pain. J Med Chem 50:2597-2600.

Guindon J, Hohmann AG (2008) Cannabinoid $\mathrm{CB}_{2}$ receptors: a therapeutic target for the treatment of inflammatory and neuropathic pain. Br J Pharmacol 153:319-334.

Gutiérrez-Adán A, Rizos D, Fair T, Moreira PN, Pintado B, de la Fuente J, Boland MP, Lonergan P (2004) Effect of speed of development on mRNA expression pattern in early bovine embryos cultured in vivo or in vitro. Mol Reprod Dev 68:441-448.

Hargreaves K, Dubner R, Brown F, Flores C, Joris J (1988) A new and sensitive method for measuring thermal nociception in cutaneous hyperalgesia. Pain 32:77-88.

Ibrahim MM, Deng H, Zvonok A, Cockayne DA, Kwan J, Mata HP, Vanderah TW, Lai J, Porreca F, Makriyannis A, Malan TP Jr (2003) Activation of CB2 cannabinoid receptors by AM1241 inhibits experimental neuropathic pain: pain inhibition by receptors not present in the CNS. Proc Natl Acad Sci USA 100:10529-10533.

Ibrahim MM, Porreca F, Lai J, Albrecht PJ, Rice FL, Khodorova A, Davar G, Makriyannis A, Vanderah TW, Mata HP, Malan TP Jr (2005) CB2 cannabinoid receptor activation produces antinociception by stimulating peripheral release of endogenous opioids. Proc Natl Acad Sci U S A 102:3093-3098.

Ibrahim MM, Rude ML, Stagg NJ, Mata HP, Lai J, Vanderah TW, Porreca F, Buckley NE, Makriyannis A, Malan TP Jr (2006) CB2 cannabinoid receptor mediation of antinociception. Pain 122:36-42.

John GR, Chen L, Rivieccio MA, MelendezVasquez CV, Hartley A, Brosnan CF (2004) Interleukin- $1 \beta$ induces a reactive astroglial phenotype via deactivation of the Rho GTPase-Rock axis. J Neurosci 24:2837-2845.

Klegeris A, Bissonnette CJ, McGeer PL (2003) Reduction of human monocytic cell neurotoxicity and cytokine secretion by ligands of the cannabinoid-type CB2 receptor. Br J Pharmacol 139:775-786.

Ledent C, Valverde O, Cossu G, Petitet F, Aubert JF, Beslot F, Böhme GA, Imperato A, Pedrazzini T, Roques BP, Vassart G, Fratta W, Parmentier M (1999) Unresponsiveness to cannabinoids and reduced addictive effects of opiates in CB1 receptor knockout mice. Science 283:401-404.

Maione S, De Petrocellis L, de Novellis V, Moriello AS, Petrosino S, Palazzo E, Rossi FS, Woodward DF, Di Marzo V (2007) Analgesic actions of $\mathrm{N}$-arachidonoyl-serotonin, a fatty acid amide hydrolase inhibitor with antagonistic activity at vanilloid TRPV1 receptors. Br J Pharmacol 150:766-781.

Malmberg AB, Basbaum AI (1998) Partial sciatic nerve injury in the mouse as a model of neuropathic pain: behavioral and neuroanatomical correlates. Pain 76:215-222.

Matsuda LA, Lolait SJ, Brownstein MJ, Young AC, Bonner TI (1990) Structure of a cannabinoid receptor and functional expression of the cloned cDNA. Nature 346:561-564.

Mitrirattanakul S, Ramakul N, Guerrero AV, Matsuka Y, Ono T, Iwase H, Mackie K, Faull KF, Spigelman I (2006) Site-specific increases in peripheral cannabinoid receptors and their endogenous ligands in a model of neuropathic pain. Pain 126:102-114. iba-1 staining

GFAP staining

\section{*}
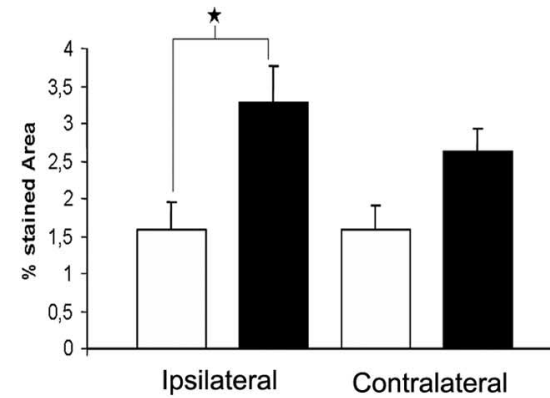

Contralateral

Sham-operated

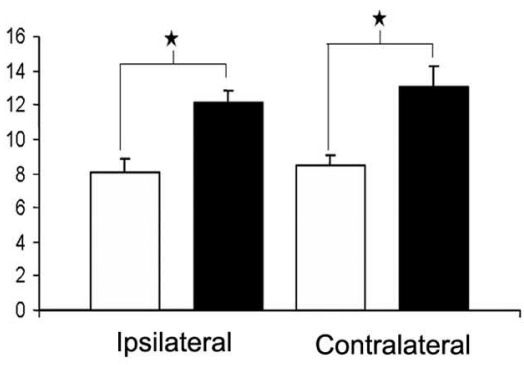

Nerve injury

Contralateral

Ipsilateral ba-1

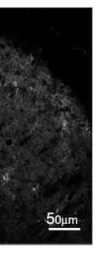

$\underline{50 \mu m}$
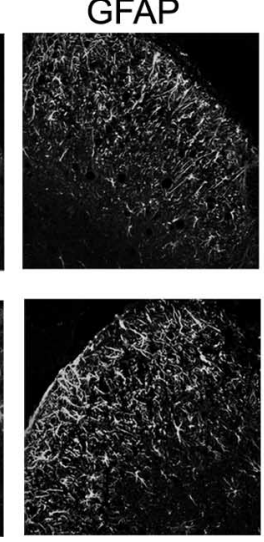

iba-1
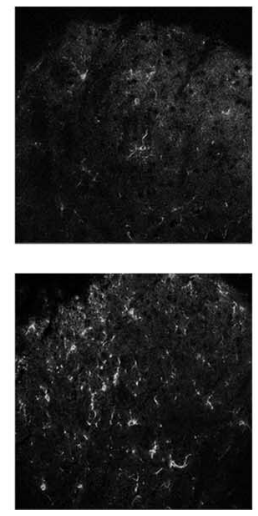
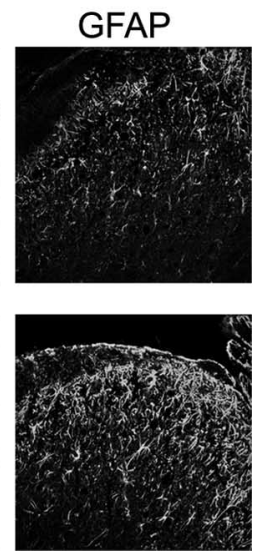

Figure 7. Histological changes in neuropathic pain after transplantation of $\mathrm{BM}$ cells lacking $\mathrm{CB}_{2}$ receptors into irradiated

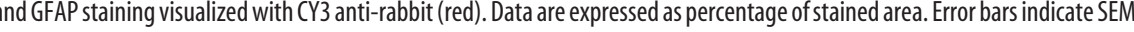
stars represent comparisons between sham-operated and nerve injury. One star, $p<0.05$; two stars, $p<0.01$. $B$ Representative confocal images of the immunostaining of iba- 1 (microglia) and GFAP (astrocyte) recorded with $40 \times$ objective in lumbar dorsal horn of sham-operated and nerve injured $\mathrm{CB}_{2}{ }^{-1-} \mathrm{BM}$-chimeric mice.

Munro S, Thomas KL, Abu-Shaar M (1993) Molecular characterization of a peripheral receptor for cannabinoids. Nature 365:61-65.

Ofek O, Karsak M, Leclerc N, Fogel M, Frenkel B, Wright K, Tam J, AttarNamdar M, Kram V, Shohami E, Mechoulam R, Zimmer A, Bab I (2006) Peripheral cannabinoid receptor, CB2, regulates bone mass. Proc Natl Acad Sci U S A 103:696-701

Palkovits M (1983) Punch sampling biopsy technique. Methods Enzymol 103:368-376.

Paxinos G, Franklin K (2001) The mouse brain in stereotaxic coordinates, Ed 2. San Diego: Academic.

Pertwee RG (2001) Cannabinoid receptors and pain. Prog Neurobiol 63:569-611.

Petrosino S, Palazzo E, de Novellis V, Bisogno T, Rossi F, Maione S, Di Marzo V (2007) Changes in spinal and supraspinal endocannabinoid levels in neuropathic rats. Neuropharmacology 52:415-422.

Puffenbarger RA, Boothe AC, Cabral GA (2000) Cannabinoids inhibits LPS-inducible cytokine mRNA expression in rat microglial cells. Glia 29:58-69.

Raghavendra V, Tanga F, DeLeo JA (2003) Inhibition of microglial activation attenuates the development but not existing hypersensitivity in a rat model of neuropathy. J Pharmacol Exp Ther 306:624-630.

Romero-Sandoval A, Eisenach JC (2007) Spinal cannabinoid receptor type 2 activation reduces hypersensitivity and spinal cord glial activation after paw incision. Anesthesiology 106:787-794.

Romero-Sandoval A, Nutile-McMenemy N, DeLeo JA (2008) Spinal micro- 
glia and perivascular cell cannabinoid receptor type 2 activation reduces behavioral hypersensitivity without tolerance after peripheral nerve injury. Anesthesiology 108:722-734.

Scholz J, Woolf CJ (2007) The neuropathic pain triad: neurons, immune cells and glia. Nat Neurosci 10:1361-1368.

Sheng WS, Hu S, Min X, Cabral GA, Lokensgard JR, Peterson PK (2005) Synthetic cannabinoid WIN55,212-2 inhibits generation of inflammatory mediators by IL-1 $\beta$-stimulated human astrocytes. Glia 49:211-219.

Steffens S, Veillard NR, Arnaud C, Pelli G, Burger F, Staub C, Karsak M, Zimmer A, Frossard JL, Mach F (2005) Low dose oral cannabinoid therapy reduces progression of atherosclerosis in mice. Nature 434:782-786.

Tanga FY, Raghavendra V, Nutile-McMenemy N, Marks A, Deleo JA (2006) Role of astrocytic S100beta in behavioral hypersensitivity in rodent models of neuropathic pain. Neuroscience 140:1003-1010.

Tóth ZE, Mezey E (2007) Simultaneous visualization of multiple antigens with tyramide signal amplification using antibodies from the same species. J Histochem Cytochem 55:545-554.

Tsou K, Brown S, Sañudo-Peña MC, Mackie K, Walker JM (1998) Immunohistochemical distribution of cannabinoid $\mathrm{CB} 1$ receptors in the rat central nervous system. Neuroscience 83:393-411.

Van Sickle MD, Duncan M, Kingsley PJ, Mouihate A, Urbani P, Mackie K, Stella N, Makriyannis A, Piomelli D, Davison JS, Marnett LJ, Di Marzo V, Pittman QJ, Patel KD, Sharkey KA (2005) Identification and functional characterization of brainstem cannabinoid CB2 receptors. Science 310:329-332.

Watkins LR, Milligan ED, Maier SF (2001) Glial proinflammatory cytokines mediate exaggerated pain states: implications for clinical pain. Trends Neurosci 24:450-455.

Watkins LR, Milligan ED, Maier SF (2003) Glial proinflammatory cytokines mediate exaggerated pain states: implications for clinical pain. Adv Exp Med Biol 521:1-21.

Whiteside GT, Lee GP, Valenzano KJ (2007) The role of the cannabinoid CB2 receptor in pain transmission and therapeutic potential of small molecule CB2 receptor agonists. Curr Med Chem 14:917-936.

Wotherspoon G, Fox A, McIntyre P, Colley S, Bevan S, Winter J (2005) Peripheral nerve injury induces cannabinoid receptor 2 protein expression in rat sensory neurons. Neuroscience 135:235-245.

Zhang J, Hoffert C, Vu HK, Groblewski T, Ahmad S, O’Donnell D (2003) Induction of $\mathrm{CB} 2$ receptor expression in the rat spinal cord of neuropathic but not inflammatory chronic pain models. Eur J Neurosci $17: 2750-2754$.

Zhang J, Shi XQ, Echeverry S, Mogil JS, De Koninck Y, Rivest S (2007) Expression of CCR2 in both resident and bone marrow-derived microglia plays a critical role in neuropathic pain. J Neurosci 27:12396-12406.

Zimmer A, Zimmer AM, Hohmann AG, Herkenham M, Bonner TI (1999) Increased mortality, hypoactivity, and hypoalgesia in cannabinoid CB1 receptor knockout mice. Proc Natl Acad Sci U S A 96:5780-5785. 